\title{
ENEOLITHIC, BABYNO AND NOUA CULTURE CEMETERIES, KLEMBIVKA, SITE 1, YAMPIL REGION, VINNITSA OBLAST: ARCHAEOMETRY, TAXONOMY AND TOPOGENETICS
}

\begin{abstract}
The paper presents excavation results and analytical studies concerning the taxonomic classification of a funerary site identified with the communities of the 'barrow cultures' settling the north-western Black Sea Coast in the first half of the 3 rd and the middle of the 2 nd millennia BC. The study focuses on the ceremonial centres of the Eneolithic communities of the Babyno and Noua cultures.
\end{abstract}

ABSTRACT

Key words: 'barrow cultures', Eneolithic, Early Bronze Age, Late Bronze Age, Middle Dniester Area

The investigations of barrow 1 in Klembivka, Yampil Region, Vinnitsa Oblast, were carried out in 2012 as part of the Polish-Ukrainian research project to invest-

\footnotetext{
* Department of Archaeology National University of Kyiv-Mohyla Academy, Skovorody 2, 04665 Kyiv, Ukraine; vklochko@ukr.net

** Institute of Prehistory Adam Mickiewicz University; Umultowska 89D, 61-614 Poznań, Poland; antokol@amu.edu.pl

*** Taras Shevchenko University; October 25 128, 3300 Tiraspol, Moldova; razum_22@rambler.ru

**** Institute of Archaeology and Ethnology of Polish Academy of Sciences, Centre for Mountains and Uplands Archaaeology in Kraków; Sławkowska 17, 31-016 Kraków, Poland; wlodarczak.piotr@gmail.com

***** Institute of Prehistory Adam Mickiewicz University; Umultowska 89D, 61-614 Poznań, Poland; danuta@amu.edu.pl
} 


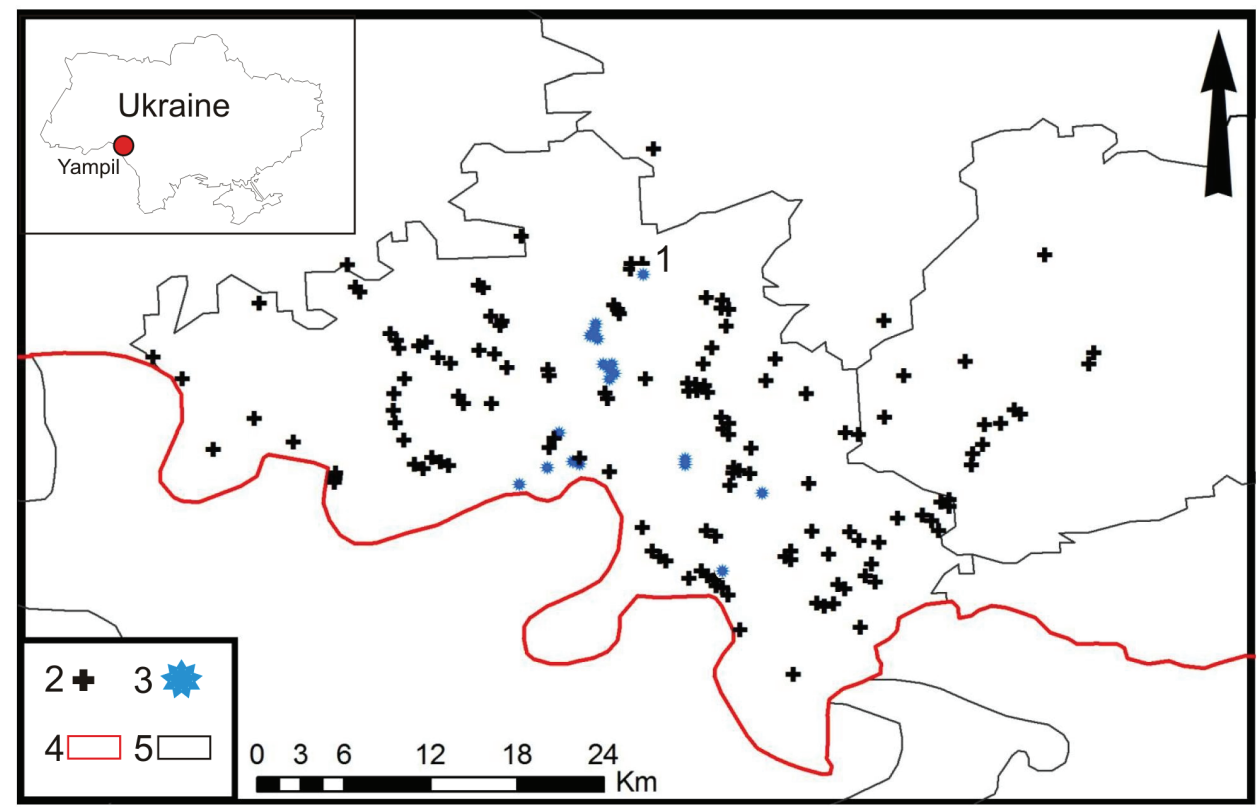

Fig. 1. Map of Yampil Barrow Complex showing administrative borders: 1 - Klembivka barrow 1; 2 - barrows; 3 - excavated barrows; 4 - Ukrainian-Moldovan frontier; 5 - Yampil Region border. After Jachimowicz 2015, revised

igate the north-western frontier of settlement by 'Early Bronze' culture communities in the Pontic zone by the Institute of Prehistory, Adam Mickiewicz University (AMU) in Poznań and the Institute of Archaeology, Ukrainian National Academy of Sciences (UNAS) in Kyiv. The project was headed by Prof. Aleksander Kośko, representing the AMU Institute of Prehistory, assisted by Dr. Piotr Włodarczak, representing the Institute of Archaeology and Ethnology, Centre for Mountains and Uplands Archaeology in Kraków (as project heads), and Dr. Serhiy Razumov, representing the Institute of Archaeology, UNAS (as expedition head).

Investigation results were first made available as a report, satisfying the conservation-archival requirements of the UNAS Institute of Archaeology in 2013 [Razumov et al. 2013]. This paper, in relation to taxonomy, takes issue with the diagnoses formulated there and presents conclusions drawn by a broader team of experts. The problem of necessary discussions aimed at adjusting the standards of applied systematics of the funeral 'Yampil' determinants of Bronze Age cultures has already been raised in some detail in an earlier paper on the Pidlisivka cemetery [Klochko et al. 2015a] ${ }^{1}$.

\footnotetext{
${ }^{1}$ Personal considerations have prevented Dr. Serhiy M. Razumov from taking part in the work of this team of experts.
} 

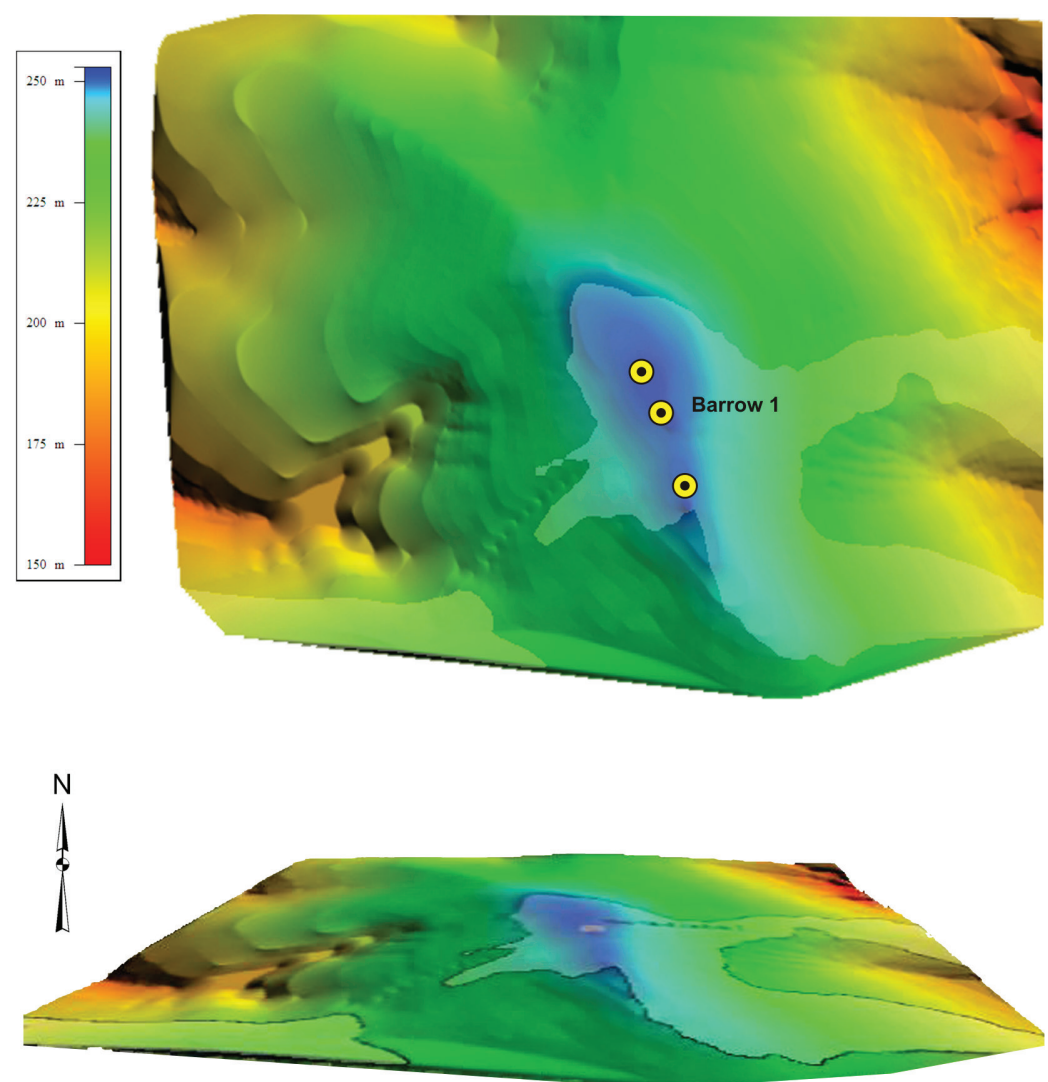

Fig. 2. Klembivka, Yampil Region. The elevation model of the immediate surroundings of site 1 and the location of neighbouring barrows (yellow dots)

1. BARROW MOUND: TOPOGRAPHY, MORPHOMETRY, STRATIGRAPHY AND SCATTER PATTERN

OF FEATURES

The Klembivka 1 site is situated on a high watershed crest extending N-S and bounded by the Rusava and Korytna river valleys. The site stands out from other barrow features investigated by the Yampil Expedition - Pidlisivka 1, Porohy 3A and Prydnistryanske 1 - by its greater distance from the Dniester (about $15 \mathrm{~km}$ ) and a fringe location on the map of Yampil barrow cluster (Fig. 1).

The investigated barrow is one of the cluster of five features of similar morphology ('tumuli') identified on the surface of the ground in the high-watershed landscape (Fig. 2). 


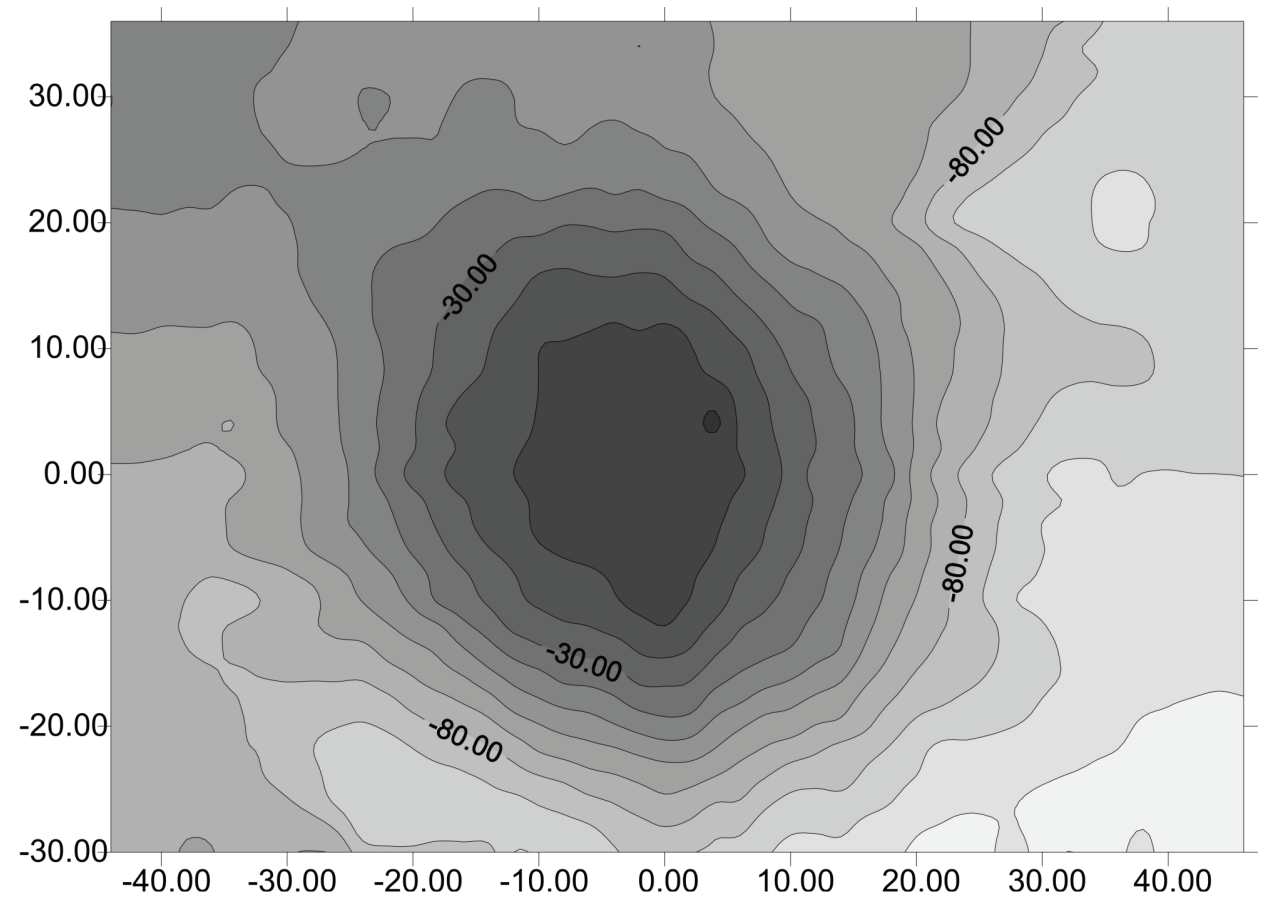

Fig. 3. Klembivka, Yampil Region, barrow 1. Site elevation plan

The analysis of mound profiles justifies distinguishing two phases of its extension (Figs. 4, 5). The older mound was built over feature 15 - an Eneolithic grave. At ground level, the mound was oval (with its longer axis extending N-S), its maximum width being $24 \mathrm{~m}$, while its height reached 0.5-0.7 m. The younger mound, in turn, was built over feature 14 - also an Eneolithic grave. At ground level, the mound was circular, with the diameter of up to $30.0 \mathrm{~m}$ and an assumed original height of up to ca. $3.0 \mathrm{~m}$ (Fig. 3). The younger mound was surrounded by a borrow pit up to $6.0 \mathrm{~m}$ wide and 0.4-0.5 $\mathrm{m}$ deep (Fig. 4). To the older mound, in turn, a stela can be linked together with features holding sacrificial animal-bone deposits (nos. 4 and 9; Fig. 6).

Into the central portion of the younger mound, feature 5 was sunk, indicating connections to the ritual module of Eneolithic societies. Other barrow-top burials include Babyno culture (BC) features - sunk into the mound (graves 1-3, 6, 8 and 10 ) and those of Noua culture (NC) societies - situated along the mound fringe (graves 7, 11-13). 


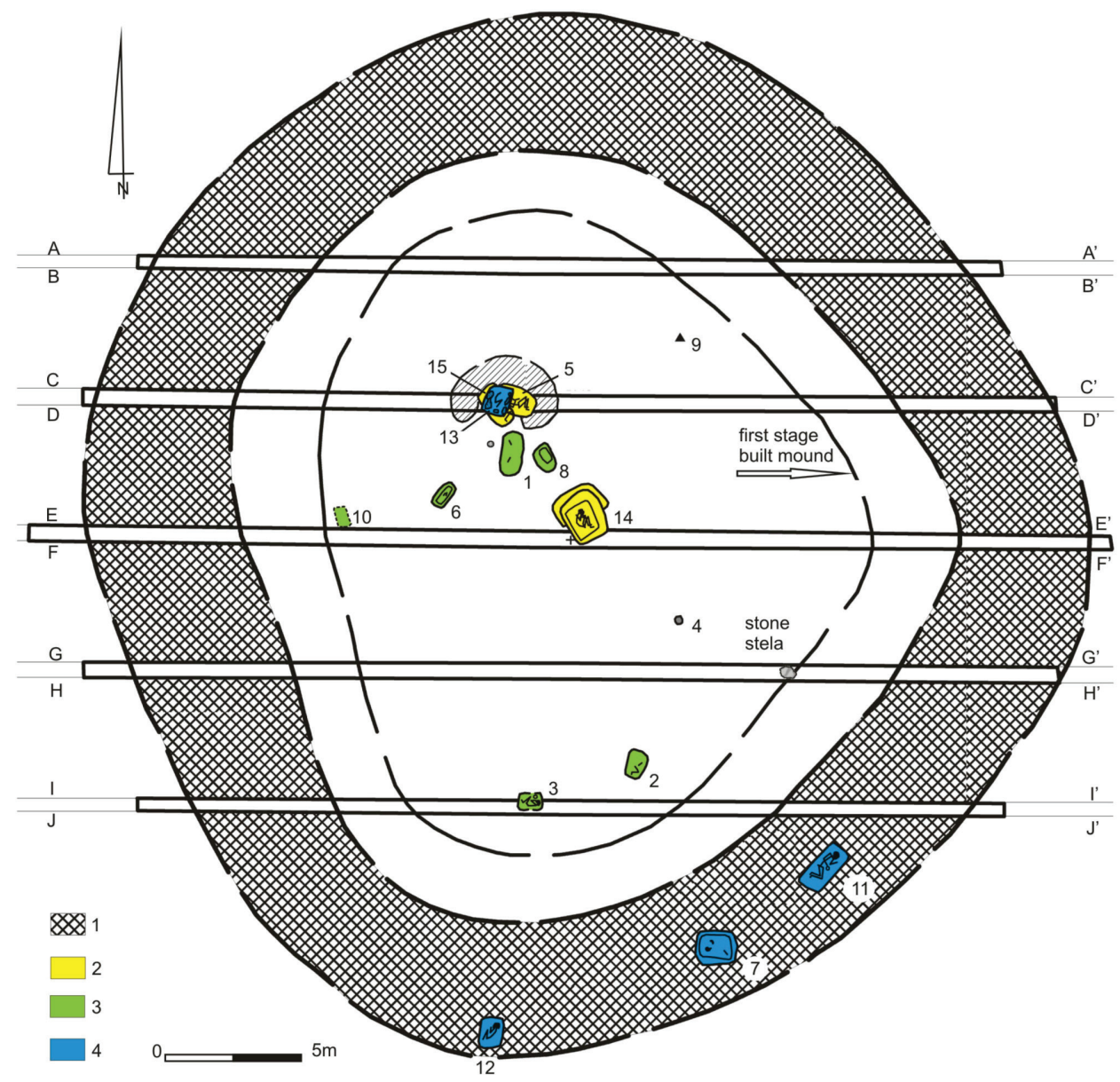

Fig. 4. Klembivka, Yampil Region. Plan of barrow 1. 1 - barrow ditch; 2 - features linked to the Eneolithic; 3 - features linked to the Babyno culture; 4 - features linked to the Noua culture

\section{FORMAL-TYPOLOGICAL DESCRIPTION OF FEATURES} AND THEIR FURNISHINGS

The descriptions of Klembivka funerary architecture traits that follow, typologically or descriptively identifiable, concern three Eneolithic graves $(5,14$ and $15)$, six BC ones $(1,2,3,6,8$ and 10), four NC ones $(7,11-13)$ and two features (4 and 9) identified as sacrificial deposits (triznas) - the derivatives of peri-funeral rites, hypothetically related to Eneolithic communities. 


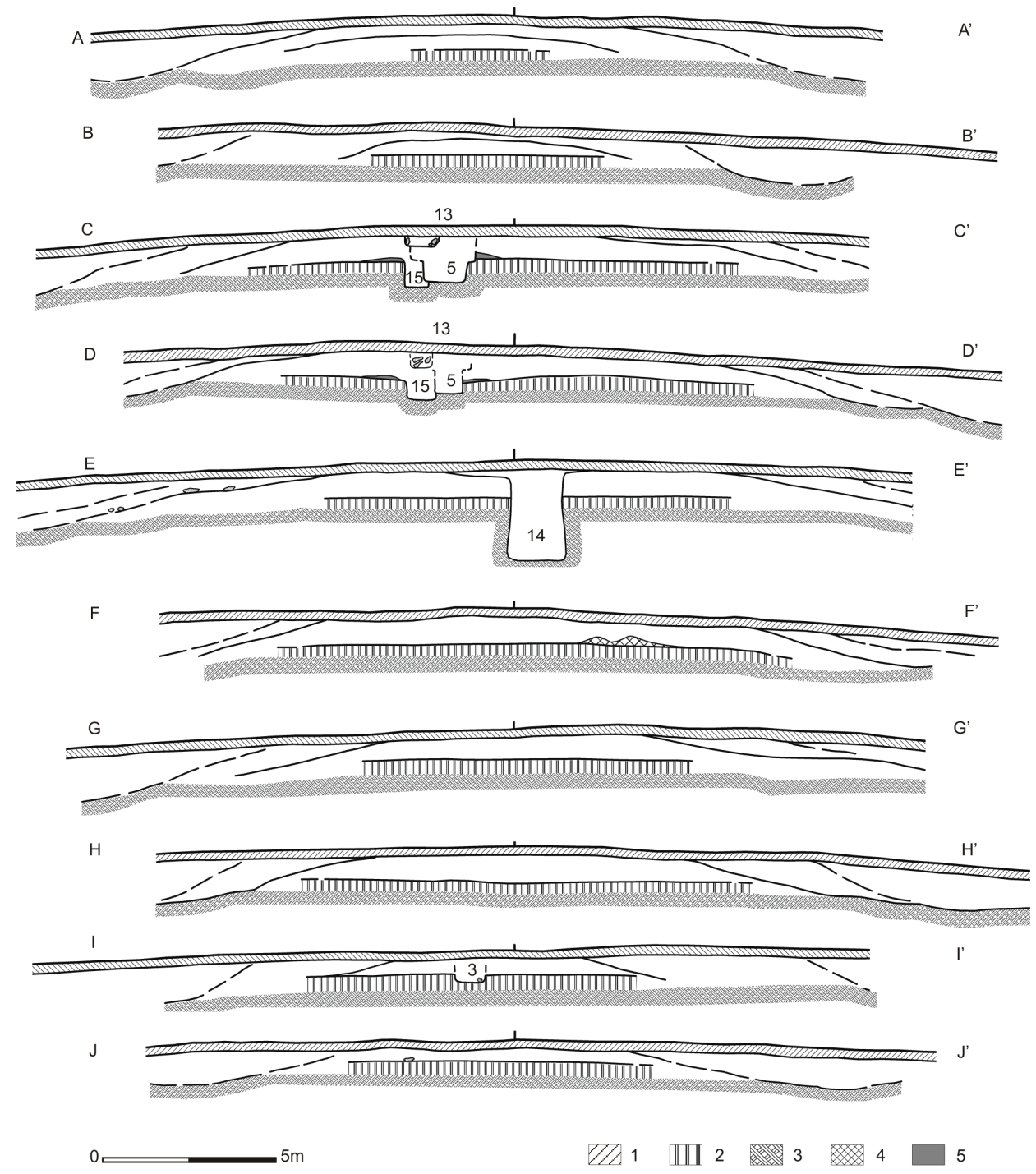

Fig. 5. Klembivka, Yampil Region. Plan of barrow 1. Barrow profiles: 1 - surface soil; 2 - original ground level; 3 - yellow loess; 4 - dark brown soil; 5 - spill of yellow loess from the grave pit

This paper has not included specialist analyses, chiefly bio-archaeological ones, to be published in one of the next volumes of Baltic-Pontic Studies (forthcoming). All the anthropological data included in the descriptions below come from the separate publication [Litvinova et al. 2015], while in the case of archaeozoological data, the assessments by O. Zhuravlov [see Razumov et al. 2013] have been used. 

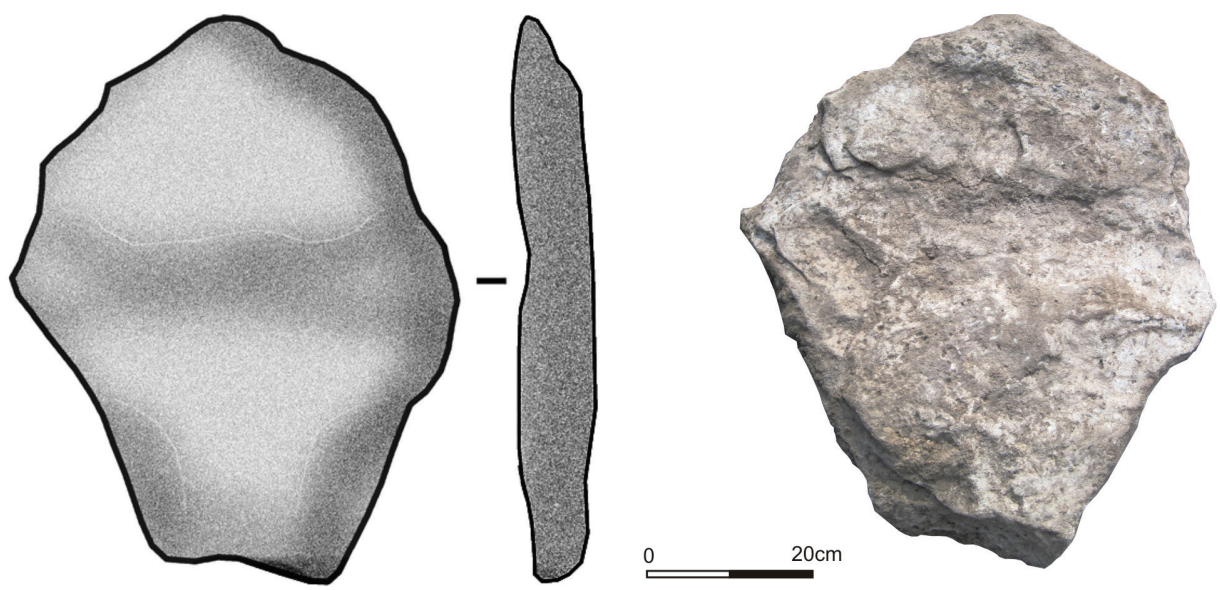

Fig. 6. Klembivka, Yampil Region, barrow 1. Stone stela - for location see Fig. 4

\section{Feature 1/1}

\begin{tabular}{|c|c|c|c|}
\hline Culture & \multicolumn{3}{|l|}{ Babyno } \\
\hline Dating & \multicolumn{3}{|c|}{ Poz-70669: $3505 \pm 35$ BP; (human bone) } \\
\hline \multicolumn{2}{|l|}{ Grave pit } & \multicolumn{2}{|l|}{ Burial } \\
\hline Structure type & Pit & Sex & $?$ \\
\hline Number of burials & $?$ & Age & $?$ \\
\hline $\begin{array}{l}\text { Size at the level } \\
\text { of discovery }\end{array}$ & $1.55 \times 0.7 \mathrm{~m}$ & Orientation & $?$ \\
\hline $\begin{array}{l}\text { Size at the level } \\
\text { of the bottom }\end{array}$ & $1.6 \times 0.7 \mathrm{~m}$ & Deviation & $?$ \\
\hline Depth & $0.8 \mathrm{~m}$ & Arrangement of head & $?$ \\
\hline Pit orientation & $\mathrm{N}-\mathrm{S}$ & Arrangement of trunk & $?$ \\
\hline Deviation & $10^{\circ} \mathrm{E}$ & Upper limbs & $?$ \\
\hline $\begin{array}{l}\text { Distance from barrow } \\
\text { centre }\end{array}$ & $1.81 \mathrm{~m}$ & Lower limbs & $?$ \\
\hline Azimuth & $165^{\circ}$ & Ochre & - \\
\hline Wooden roofing & - & Presence of mat & - \\
\hline $\begin{array}{l}\text { Roofing element } \\
\text { orientation }\end{array}$ & & Animal bones & $\begin{array}{l}\text { Single bones of a pig } \\
\text { and cow }\end{array}$ \\
\hline $\begin{array}{l}\text { Other structural } \\
\text { elements }\end{array}$ & $\begin{array}{l}\text { Fragment of stone } \\
\text { slabs in feature ceiling }\end{array}$ & Ritual objects & - \\
\hline Comments & \multicolumn{3}{|c|}{$\begin{array}{l}\text { About } 0.4 \mathrm{~m} \text { E, at a depth } 0.32 \mathrm{~m} \text { from the pit the bottom part of a ves- } \\
\text { sel was found. }\end{array}$} \\
\hline
\end{tabular}


The feature was sunk into the central portion of the barrow. A rectangular pit held many limestone slab fragments at various depths, being probably elements of a pit cover or lining. Close to the bottom, only single fragments of long bones of a cow and pig were found. At a distance of $0.4 \mathrm{~m}$ east of the pit, immediately below the surface soil, a discovery was made of a vessel base (its upper portion had been destroyed by ploughing) (Figs. 7, 8).

\section{Inventory}

1. The base of a hand-made vessel with a flat bottom, ornamented with horizontal and oblique flat coils. The ceramic body contains temper of fine sand and crushed ceramics. The outer surface is smoothed out and blotched (yellow and grey). The inner surface is even, burnished and black. Dimensions: bottom diameter $-11.7 \mathrm{~cm}$, height of the surviving portion $-10.0 \mathrm{~cm}$, wall thickness -0.9 $-1.0 \mathrm{~cm}$, bottom thickness $-1.4 \mathrm{~cm}$ (Fig. $7: 2$ ).

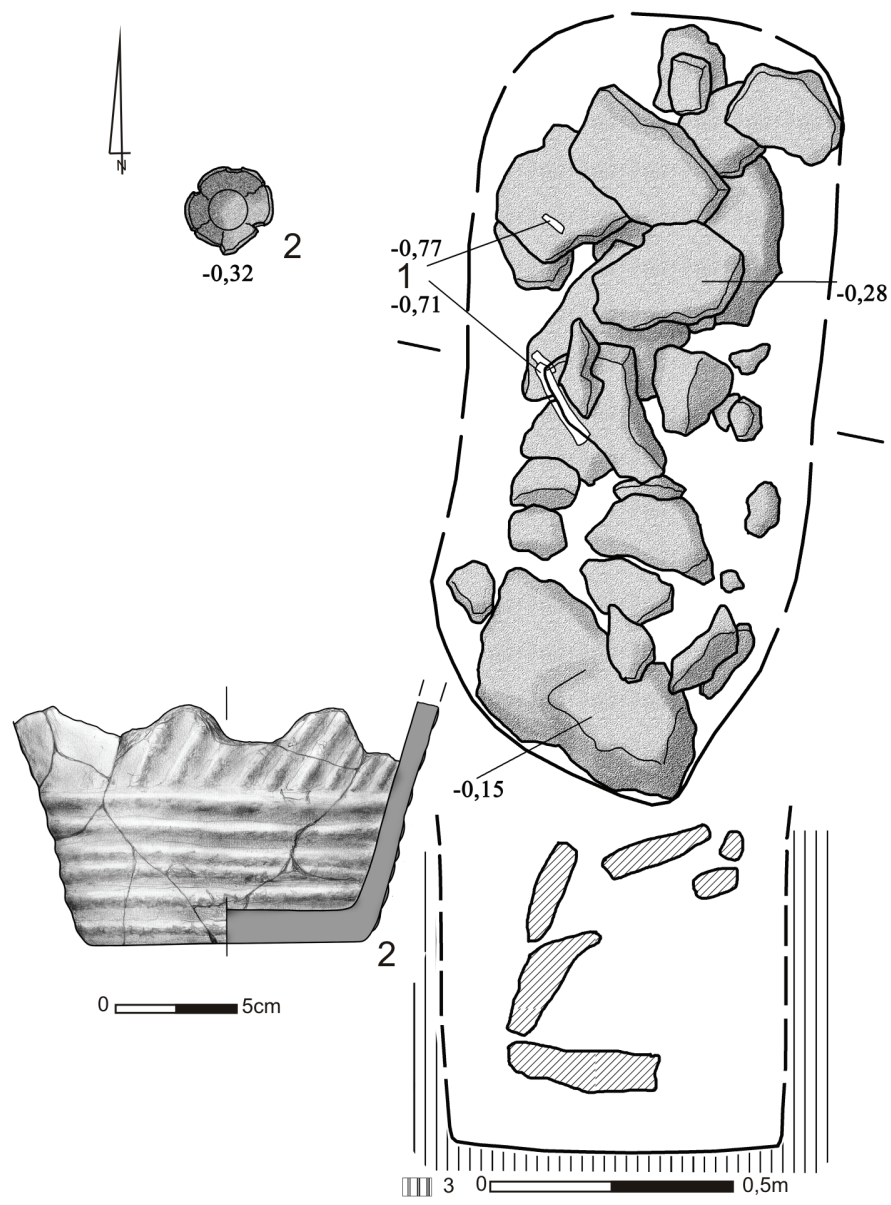

Fig. 7. Klembivka, Yampil Region, barrow 1. Plan and profile of feature 1/1. 1 - pig bones; 2 - base of a vessel; 3 - mound strata 


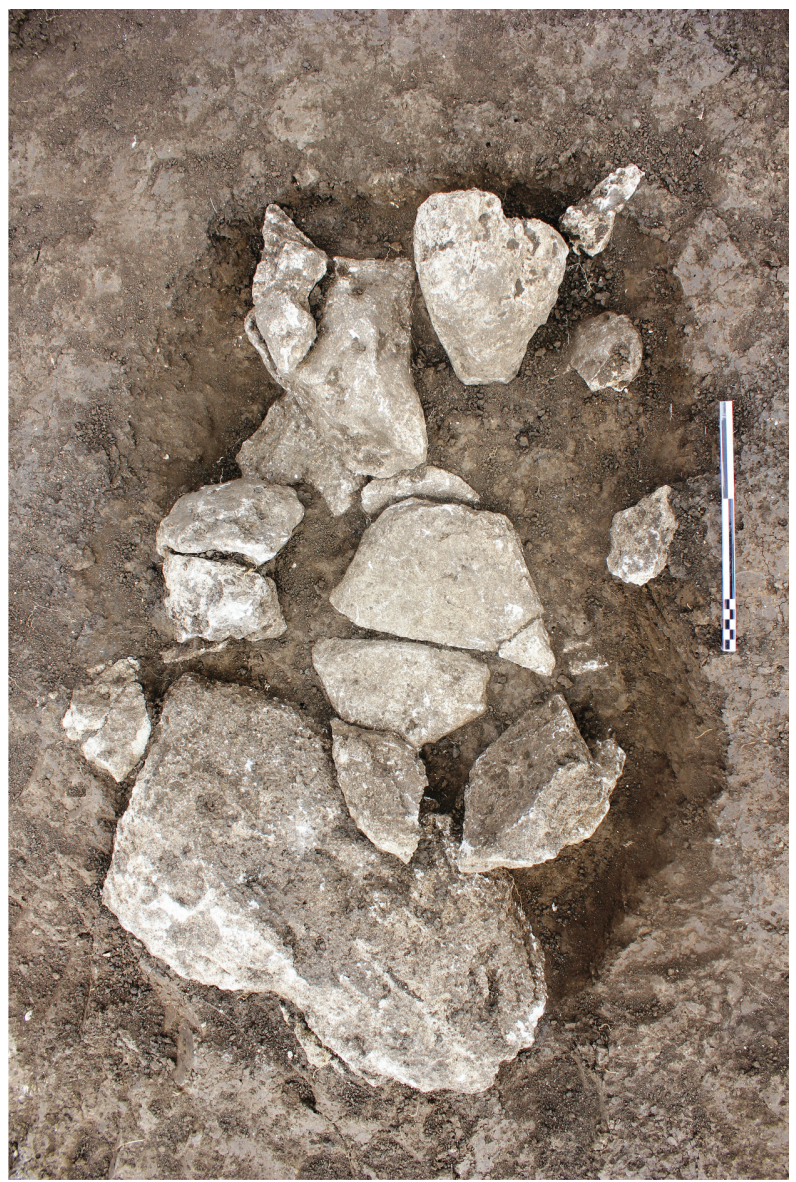

Fig. 8 . Klembivka, Yampil Region, barrow 1, feature 1/1 - horizontal projection of feature ceiling

Feature 1/2

\begin{tabular}{|l|l|l|l|}
\hline Culture & \multicolumn{2}{|l|}{ Babyno } \\
\hline Dating & \multicolumn{3}{|l|}{} \\
\hline Grave pit & Burial & $?$ \\
\hline Structure type & Pit & Sex & Adult \\
\hline Number of burials & 1 & Age & NE-SW \\
\hline $\begin{array}{l}\text { Size at the level } \\
\text { of discovery }\end{array}$ & $0.9 \times 0.7 \mathrm{~m}$ & Orientation & $?$ \\
\hline $\begin{array}{l}\text { Size at the level } \\
\text { of the bottom }\end{array}$ & $0.9 \times 0.7 \mathrm{~m}$ & Deviation & \\
\hline
\end{tabular}




\begin{tabular}{|l|l|l|l|}
\hline Depth & $1.55 \mathrm{~m}$ & Arrangement of head & $?$ \\
\hline Pit orientation & N-E & Arrangement of trunk & L? \\
\hline Deviation & $21^{\circ} \mathrm{E}$ & Upper limbs & $?$ \\
\hline $\begin{array}{l}\text { Distance from barrow } \\
\text { centre }\end{array}$ & $14.2 \mathrm{~m}$ & Lower limbs & $2 ?$ \\
\hline Azimuth & $159^{\circ}$ & Ochre & - \\
\hline Wooden roofing & - & Presence of mat & - \\
\hline $\begin{array}{l}\text { Roofing element } \\
\text { orientation }\end{array}$ & Animal bones & - \\
\hline $\begin{array}{l}\text { Other structural } \\
\text { elements }\end{array}$ & - & Ritual objects & - \\
\hline Comments & & & \\
\hline
\end{tabular}

A pit grave sunk into the southern portion of the mound. A rectangular pit held on its bottom a poorly-preserved skeleton, damaged by many animal burrows. From the few remains, it can be presumed that the deceased was laid crouched on the left side, with the head pointing NE (Fig. 9).
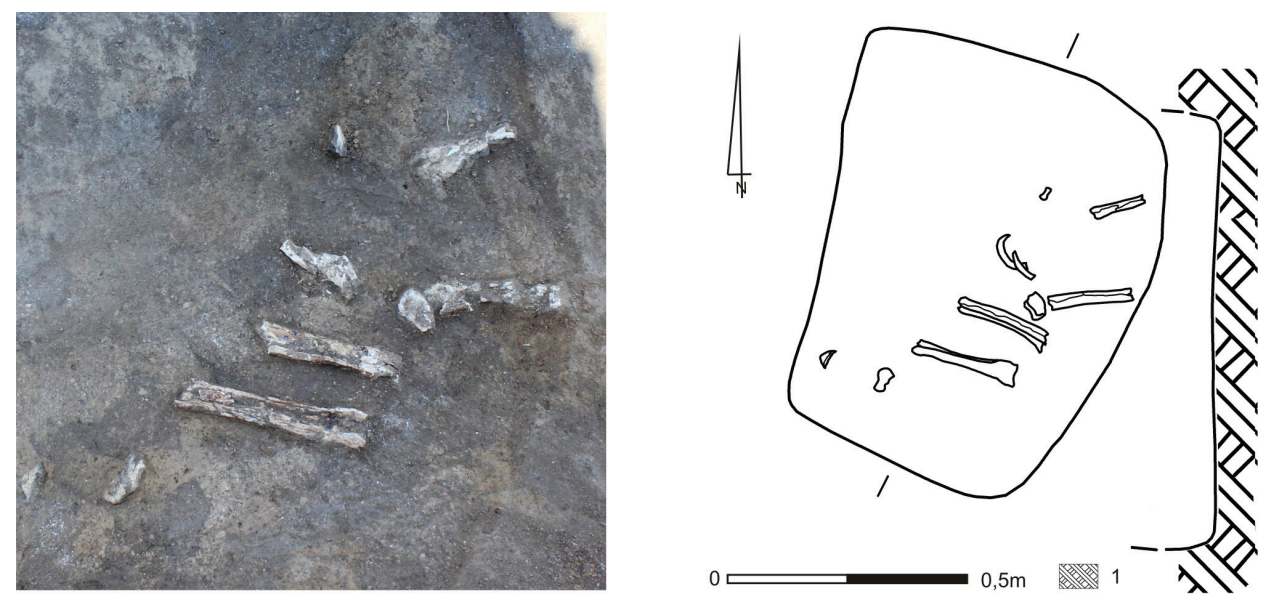

Fig. 9. Klembivka, Yampil Region, barrow 1, feature 1/2. Horizontal and vertical projections of feature. 1 - yellow loess 
Feature 1/3

\begin{tabular}{|c|c|c|c|}
\hline Culture & \multicolumn{3}{|l|}{ Babyno } \\
\hline Dating & \multicolumn{3}{|c|}{ Poz-74398: $3495 \pm 35$ BP (human bone) } \\
\hline \multicolumn{2}{|l|}{ Grave pit } & \multicolumn{2}{|l|}{ Burial } \\
\hline Structure type & Pit & Sex & Male \\
\hline Number of burials & 1 & Age & $35-45$ years \\
\hline $\begin{array}{l}\text { Size at the level } \\
\text { of discovery }\end{array}$ & $0.9 \times 0.65 \mathrm{~m}$ & Orientation & E-W \\
\hline $\begin{array}{l}\text { Size at the level } \\
\text { of the bottom }\end{array}$ & $0.9 \times 0.6 \mathrm{~m}$ & Deviation & $?$ \\
\hline Depth & $1.31 \mathrm{~m}$ & Arrangement of head & $\mathrm{P}$ \\
\hline Pit orientation & E-W & Arrangement of trunk & $\mathrm{P} ?$ \\
\hline Deviation & $0^{\circ}$ & Upper limbs & $\mathrm{D} ?$ \\
\hline $\begin{array}{l}\text { Distance from barrow } \\
\text { centre }\end{array}$ & $14.66 \mathrm{~m}$ & Lower limbs & $1 ?$ \\
\hline Azimuth & $175^{\circ}$ & Ochre & - \\
\hline Wooden roofing & - & Presence of mat & - \\
\hline $\begin{array}{l}\text { Roofing element } \\
\text { orientation }\end{array}$ & & Animal bones & - \\
\hline $\begin{array}{l}\text { Other structural } \\
\text { elements }\end{array}$ & - & Ritual objects & Vessel \\
\hline Comments & & & \\
\hline
\end{tabular}

A pit grave sunk into the southern portion of the mound. A rectangular pit held on its bottom the poorly-preserved skeleton of an adult male, damaged by many animal burrows. The deceased was laid crouched on the right side. At the upper limb bones, a ceramic vessel lay (Fig. 10).

\section{Inventory}

1. A small, S-profiled vessel with an unmarked, slightly concave base. Its outer surface is even, smoothed out, yellow and grey in colour; the inner surface is even, mat, and burnished in the upper portion of the vessel. The ceramic body contains fine-grain temper of crushed ceramics and sand. Dimensions: height $-8.5 \mathrm{~cm}$, mouth diameter $-10.9 \mathrm{~cm}$, neck diameter $-10.0 \mathrm{~cm}$, belly diameter $-10.2 \mathrm{~cm}$, bottom diameter $-8.0 \mathrm{~cm}$, wall thickness $-0.8-1.0 \mathrm{~cm}$ (Fig. 10: 2). 


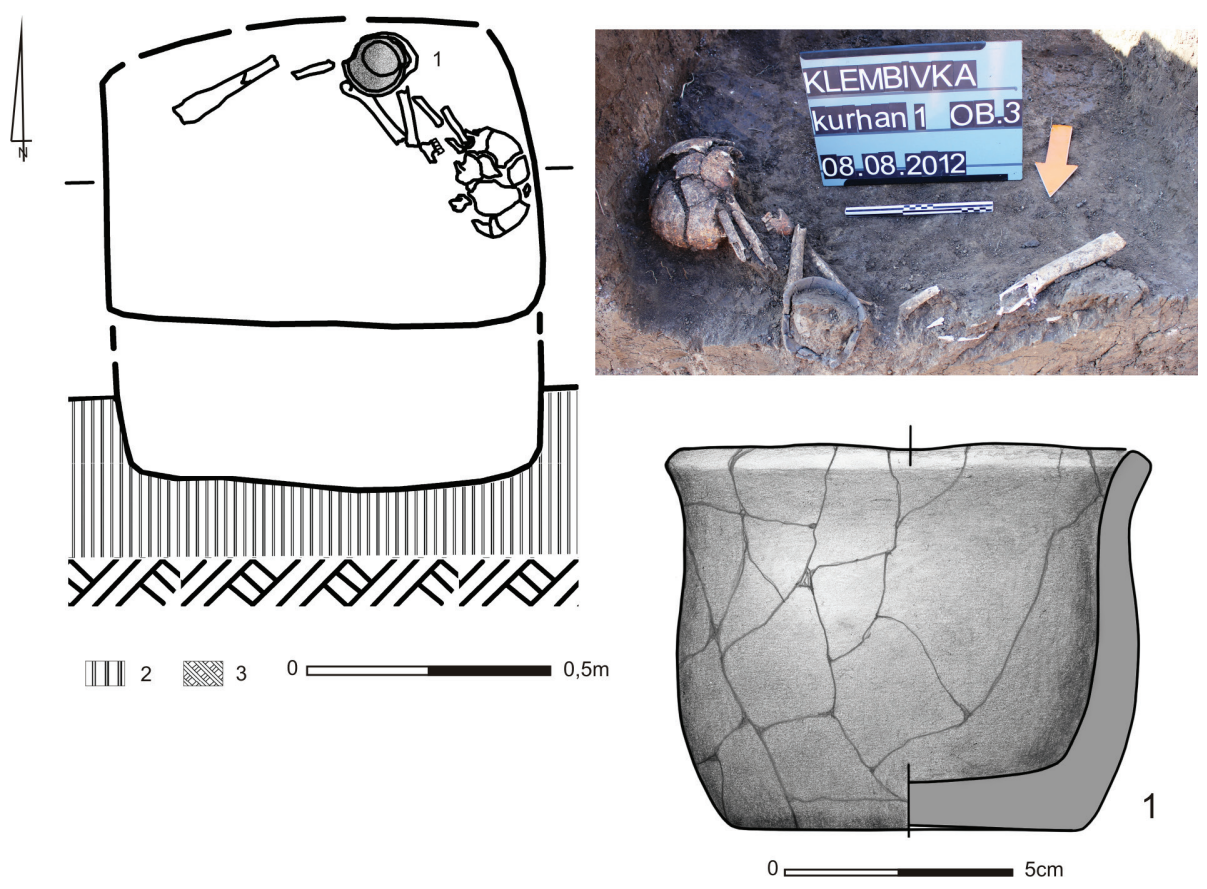

Fig. 10 . Klembivka, Yampil Region, barrow 1, feature 1/3. Horizontal and vertical projections of feature. 1 - ceramic vessel; 2 - original ground level; 3 - yellow loess

Feature 1/4

\begin{tabular}{|l|l|}
\hline Culture & Eneolithic \\
\hline Dating & \\
\hline Structure type & $?$ \\
\hline Size at the level of discovery & $?$ \\
\hline Size at the level of the bottom & $0.3 \times 0.3 \mathrm{~m}$ \\
\hline Depth & $1.7 \mathrm{~m}$ \\
\hline Pit orientation & \\
\hline Deviation & \\
\hline Distance from barrow centre & $10 \mathrm{~m}$ \\
\hline Azimuth & $140^{\circ}$ \\
\hline Animal bones & $\begin{array}{l}\text { Roe deer bone and } 28 \text { other indeterminate } \\
\text { bones }\end{array}$ \\
\hline Ritual objects & - \\
\hline Comments & \\
\hline
\end{tabular}



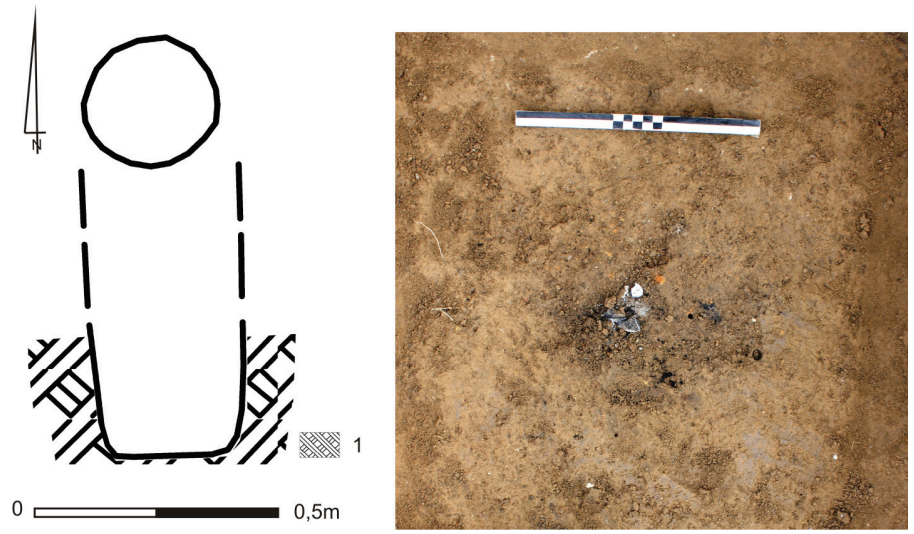

Fig. 11. Klembivka, Yampil Region, barrow 1, feature 1/4. Horizontal and vertical projections of feature. 1 - yellow loess

A (sacrificial?) pit dug from the original ground level before the older mound was built. It was circular in horizontal projection. Its depth, measured from the original ground level, was $0.6 \mathrm{~m}$. The central and bottom parts of the fill were made up of burned soil and charcoals. Within the fill, 29 small calcified animal bones were discovered (one was identified as a roe deer bone) (Fig. 11).

Feature $1 / 5$

\begin{tabular}{|l|l|l|l|}
\hline Culture & \multicolumn{2}{|l|}{ Eneolithic? } \\
\hline Dating & \multicolumn{2}{|l|}{ Poz-70670: 4225 $\pm 35 \mathrm{BP}$ (human bone) } \\
\hline Grave pit & \multicolumn{2}{|l|}{ Burial } & Male \\
\hline Structure type & Pit/semi-niche & Sex & $50-55$ years \\
\hline Number of burials & 1 & Age & W-E \\
\hline $\begin{array}{l}\text { Size at the level } \\
\text { of discovery }\end{array}$ & $?$ & Orientation & $13^{\circ} \mathrm{N}$ \\
\hline $\begin{array}{l}\text { Size at the level } \\
\text { of the bottom }\end{array}$ & $1.85 \times 0.95 \mathrm{~m}$ & Deviation & L \\
\hline Depth & $1.45 \mathrm{~m}$ & Arrangement of head & Supine \\
\hline Pit orientation & W-E & Arrangement of trunk & A \\
\hline Deviation & $6^{\circ} \mathrm{S}$ & Upper limbs & 2 \\
\hline $\begin{array}{l}\text { Distance from barrow } \\
\text { centre }\end{array}$ & $0.73 \mathrm{~m}$ & Lower limbs & - \\
\hline Azimuth & $90^{\circ}$ & Ochre & - \\
\hline Wooden roofing & - & Presence of mat & - \\
\hline $\begin{array}{l}\text { Roofing element } \\
\text { orientation }\end{array}$ & & Animal bones & \\
\hline
\end{tabular}




\begin{tabular}{|l|l|l|l|}
\hline $\begin{array}{l}\text { Other structural } \\
\text { elements }\end{array}$ & - & Ritual objects & - \\
\hline Comments & \multicolumn{3}{|l|}{} \\
\hline
\end{tabular}

The grave was sunk into the central portion of the barrow, probably from the level of the older barrow. The pit was irregular in shape, resembling a rectangle with rounded corners. On its bottom, the well-preserved skeleton of an adult male lay crouched, supine, with the head and lower limbs turned to the left side. On the left zygomatic bone, there was a trace of a deep injury (Fig. 12).
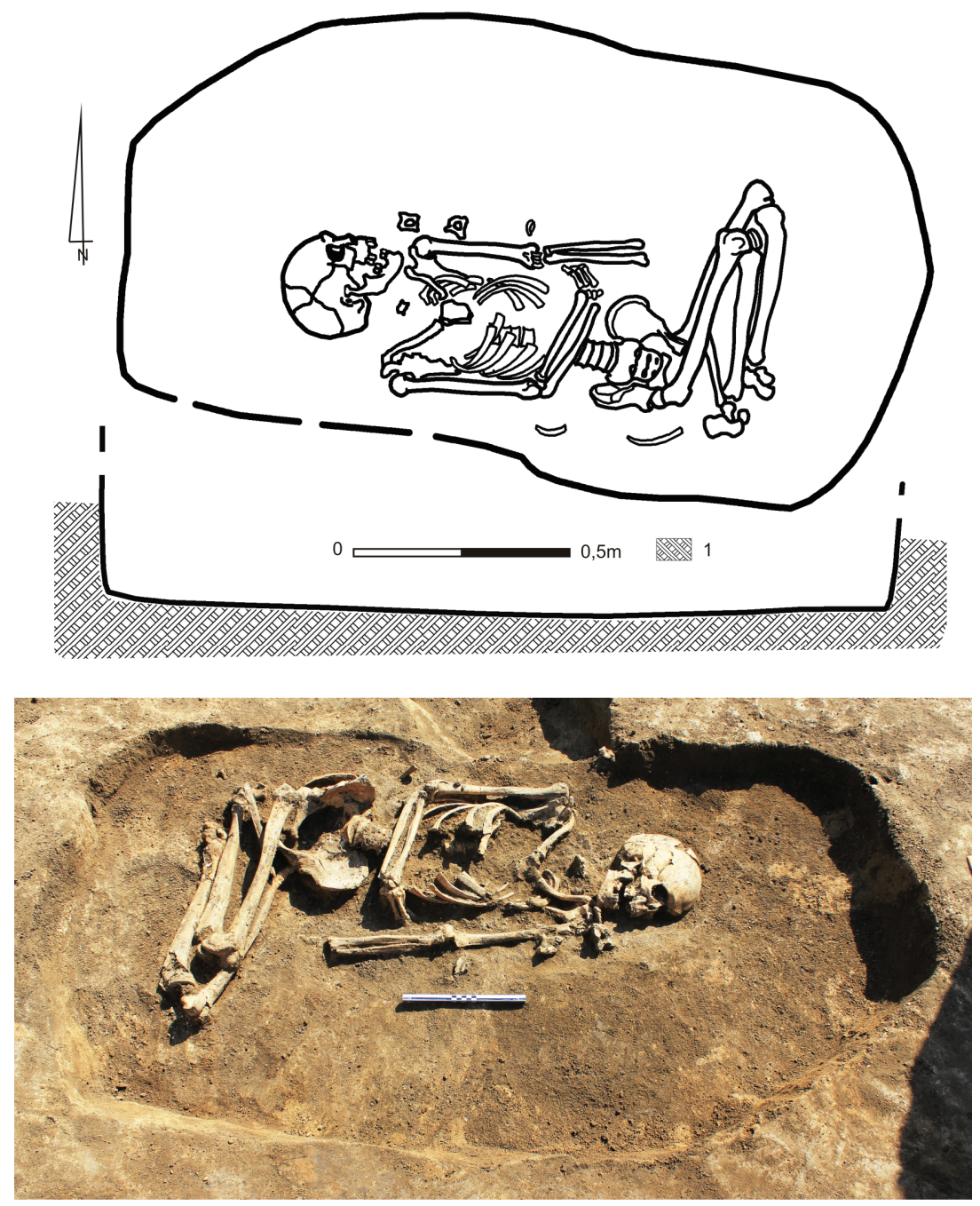

Fig. 12. Klembivka, Yampil Region, barrow 1, feature 1/5. Horizontal and vertical projections of burial. 1 - yellow loess 

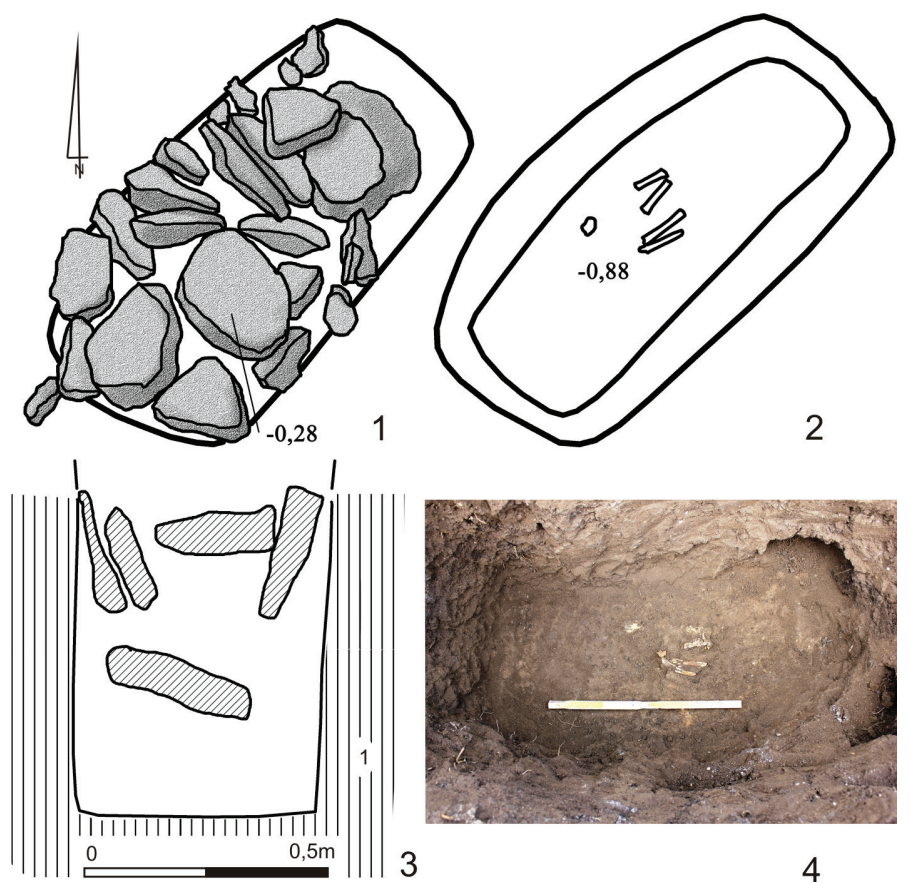

3

4

Fig. 13. Klembivka, Yampil Region, barrow 1, feature 1/6. 1 - horizontal projection of feature ceiling; 2, 4- horizontal projection of feature floor; 3 - vertical projection of feature; 1 - barrow mound

Feature $1 / 6$

\begin{tabular}{|l|l|l|l|}
\hline \multicolumn{2}{|l|}{ Culture } & \multicolumn{2}{l|}{ Babyno } \\
\hline Dating & \multicolumn{2}{l|}{} \\
\hline Grave pit & \multicolumn{2}{l|}{ Burial } & $?$ \\
\hline Structure type & Pit & Sex & Infans \\
\hline Number of burials & 1 & Age & SW-NE? \\
\hline $\begin{array}{l}\text { Size at the level } \\
\text { of discovery }\end{array}$ & $1.0 \times 0.55 \mathrm{~m}$ & Orientation & $?$ \\
\hline $\begin{array}{l}\text { Size at the level } \\
\text { of the bottom }\end{array}$ & $0.9 \times 0.35 \mathrm{~m}$ & Deviation & $?$ \\
\hline Depth & $0.9 \mathrm{~m}$ & Arrangement of head & $?$ \\
\hline Pit orientation & SW-NE & Arrangement of trunk & $?$ \\
\hline Deviation & $0^{\circ}$ & Upper limbs & $?$ \\
\hline $\begin{array}{l}\text { Distance from barrow } \\
\text { centre }\end{array}$ & $3.8 \mathrm{~m}$ & Lower limbs & $?$ \\
\hline Azimuth & $211^{\circ}$ & Ochre & - \\
\hline
\end{tabular}




\begin{tabular}{|l|l|l|l|}
\hline Wooden roofing & - & Presence of mat & - \\
\hline $\begin{array}{l}\text { Roofing element } \\
\text { orientation }\end{array}$ & Animal bones & - \\
\hline $\begin{array}{l}\text { Other structural } \\
\text { elements }\end{array}$ & $\begin{array}{l}\text { grave cover of stone } \\
\text { slabs }\end{array}$ & Ritual objects & - \\
\hline Comments & \multicolumn{2}{|l|}{} \\
\hline
\end{tabular}

The grave was sunk into the western portion of the mound. A rectangular pit held in its fill a pile of lime stones. On the bottom, fragments of bones belonging to an infant were found (Fig. 13).

Feature 1/7

\begin{tabular}{|c|c|c|c|}
\hline Culture & \multicolumn{3}{|l|}{ Noua } \\
\hline Dating & \multicolumn{3}{|c|}{ Poz-74399: $3130 \pm 35$ BP (human bone) } \\
\hline \multicolumn{2}{|l|}{ Grave pit } & \multicolumn{2}{|l|}{ Burial } \\
\hline Structure type & Pit & Sex & $\begin{array}{l}\text { 1. Male? } \\
\text { 2. ? } \\
\text { 3. Female? }\end{array}$ \\
\hline Number of burials & 3 & Age & $\begin{array}{l}\text { 1. Maturus } \\
\text { 2. 4-5 years } \\
\text { 3. Maturus }\end{array}$ \\
\hline $\begin{array}{l}\text { Size at the level } \\
\text { of discovery }\end{array}$ & $1.35 \times 1.25 \mathrm{~m}$ & Orientation & $\begin{array}{l}\text { 1.? } \\
\text { 2.? } \\
\text { 3.? }\end{array}$ \\
\hline $\begin{array}{l}\text { Size at the level } \\
\text { of the bottom }\end{array}$ & $1.14 \times 0.95 \mathrm{~m}$ & Deviation & $\begin{array}{l}\text { 1.? } \\
\text { 2.? } \\
\text { 3.? }\end{array}$ \\
\hline Depth & $1.5 \mathrm{~m}$ & Arrangement of head & $\begin{array}{l}\text { 1.? } \\
\text { 2.? } \\
\text { 3.? }\end{array}$ \\
\hline Pit orientation & W-E & Arrangement of trunk & $\begin{array}{l}\text { 1.? } \\
\text { 2.? } \\
\text { 3.? }\end{array}$ \\
\hline Deviation & $0^{\circ}$ & Upper limbs & $\begin{array}{l}\text { 1.? } \\
\text { 2.? } \\
\text { 3.? }\end{array}$ \\
\hline $\begin{array}{l}\text { Distance from barrow } \\
\text { centre }\end{array}$ & $21.6 \mathrm{~m}$ & Lower limbs & $\begin{array}{l}\text { 1.? } \\
\text { 2.? } \\
\text { 3.? }\end{array}$ \\
\hline Azimuth & $158^{\circ}$ & Ochre & - \\
\hline Wooden roofing & - & Presence of mat & - \\
\hline $\begin{array}{l}\text { Roofing element } \\
\text { orientation }\end{array}$ & & Animal bones & - \\
\hline $\begin{array}{l}\text { Other structural } \\
\text { elements }\end{array}$ & $\begin{array}{l}\text { Stone on the feature } \\
\text { bottom }\end{array}$ & Ritual objects & - \\
\hline Comments & \multicolumn{3}{|l|}{ Robbed? } \\
\hline
\end{tabular}



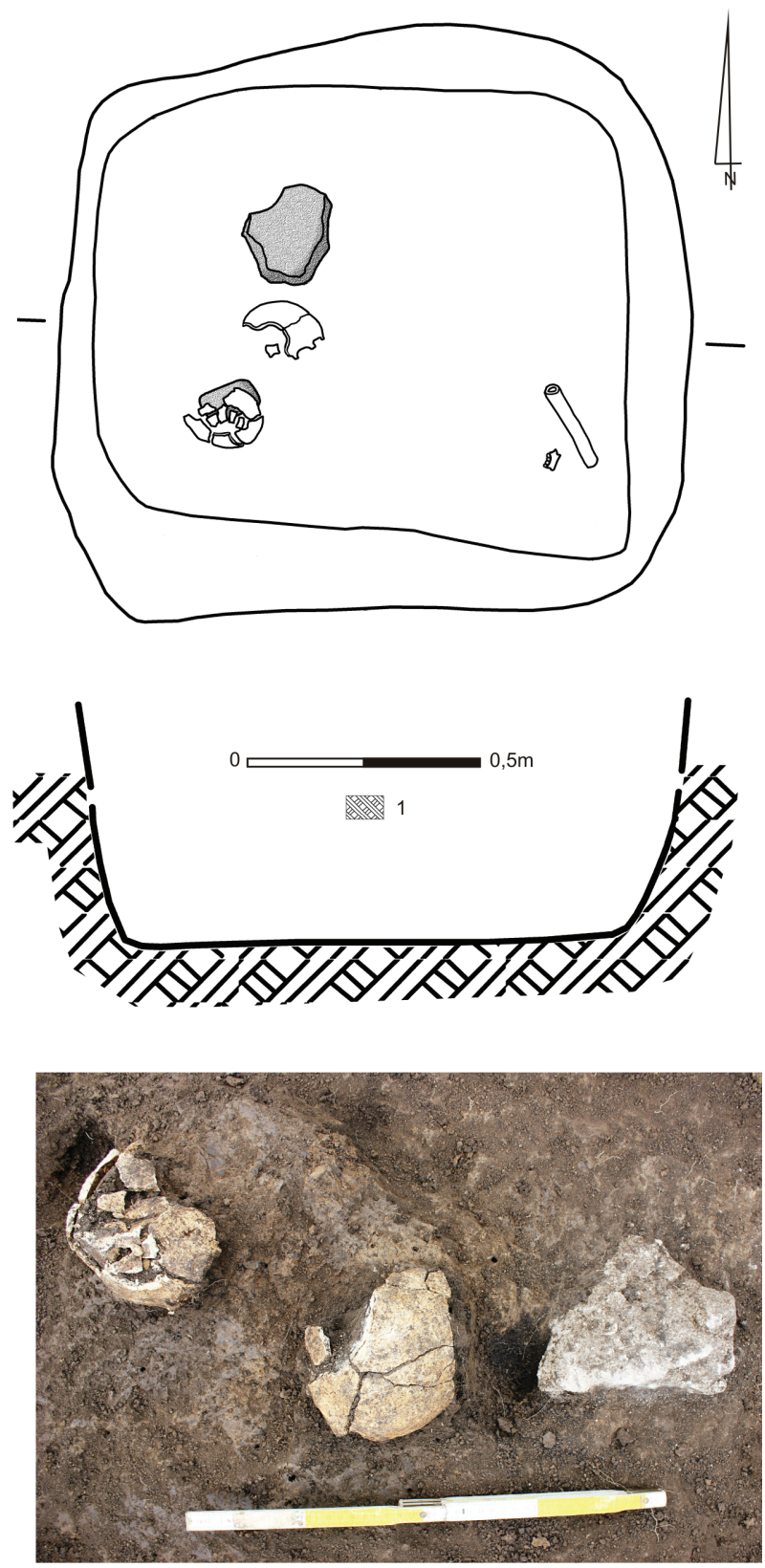

Fig. 14. Klembivka, Yampil Region, barrow 1, feature 1/7. Horizontal and vertical projections of feature. 1 - yellow loess 
The grave was sunk into the barrow ditch at the southern edge of the younger mound. The upper portion of the pit was almost square and had rounded corners. The burial was secondarily disturbed (robbed?). Single bones of three individuals (two adults and a child) were recovered from various levels of the fill (beginning from a depth of about $1.0 \mathrm{~m}$ ). They were accompanied by few small lime stones (Fig. 14).

Feature 1/8

\begin{tabular}{|c|c|c|c|}
\hline Culture & \multicolumn{3}{|l|}{ Babyno } \\
\hline \multicolumn{4}{|l|}{ Dating } \\
\hline \multicolumn{2}{|l|}{ Grave pit } & \multicolumn{2}{|l|}{ Burial } \\
\hline Structure type & Pit & Sex & $?$ \\
\hline Number of burials & $?$ & Age & $?$ \\
\hline $\begin{array}{l}\text { Size at the level } \\
\text { of discovery }\end{array}$ & $1.3 \times 1.15 \mathrm{~m}$ & Orientation & $?$ \\
\hline $\begin{array}{l}\text { Size at the level } \\
\text { of the bottom }\end{array}$ & $0.95 \times 0.65 \mathrm{~m}$ & Deviation & $?$ \\
\hline Depth & $1.4 \mathrm{~m}$ & Arrangement of head & $?$ \\
\hline Pit orientation & SE-NW & Arrangement of trunk & $?$ \\
\hline Deviation & $0^{\circ}$ & Upper limbs & $?$ \\
\hline $\begin{array}{l}\text { Distance from barrow } \\
\text { centre }\end{array}$ & $2.62 \mathrm{~m}$ & Lower limbs & $?$ \\
\hline Azimuth & $137^{\circ}$ & Ochre & - \\
\hline Wooden roofing & - & Presence of mat & - \\
\hline $\begin{array}{l}\text { Roofing element } \\
\text { orientation }\end{array}$ & & Animal bones & - \\
\hline $\begin{array}{l}\text { Other structural } \\
\text { elements }\end{array}$ & $\begin{array}{l}\text { Grave cover of stone } \\
\text { slabs }\end{array}$ & Ritual objects & - \\
\hline Comments & \multicolumn{3}{|c|}{ Secondarily disturbed? The fill contained fine bones. } \\
\hline
\end{tabular}

The grave was secondarily sunk into the central portion of the mound. An irregularly shaped, rectangular pit narrowed down towards the floor. It was filled with rubble of lime stones (at a depth from 0.2 to $0.85 \mathrm{~m}$ ). Inside it, there were fine fragments of human bones. The character of the fill indicates that the feature was secondarily disturbed (robbed?). 


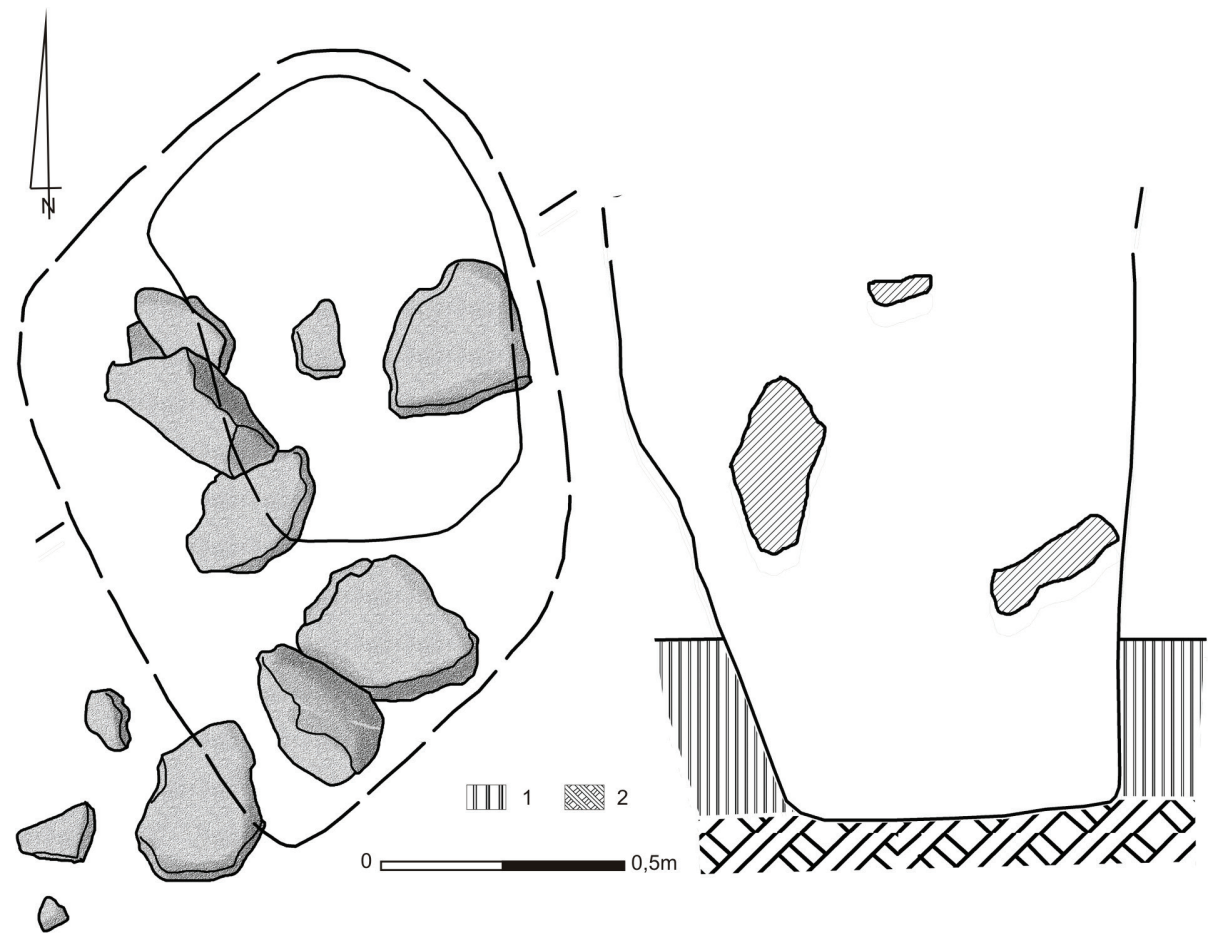

Fig. 15. Klembivka, Yampil Region, barrow 1, feature 1/8. Horizontal and vertical projections of feature. 1 - original ground level; 2 - yellow loess

\section{Feature 1/9}

\begin{tabular}{|l|l|}
\hline Culture & Eneolithic? \\
\hline Dating & \\
\hline Structure type & $?$ \\
\hline Size at the level of discovery & $?$ \\
\hline Size at the level of the bottom & $0.45 \times 0.45 \mathrm{~m}$ \\
\hline Depth & $1.2 \mathrm{~m}$ \\
\hline Pit orientation & $?$ \\
\hline Deviation & $?$ \\
\hline Distance from barrow centre & $7.22 \mathrm{~m}$ \\
\hline Azimuth & $109^{\circ}$ \\
\hline Animal bones & 11 frag. of sheep/goat bones \\
\hline Ritual objects & - \\
\hline Comments & \\
\hline
\end{tabular}




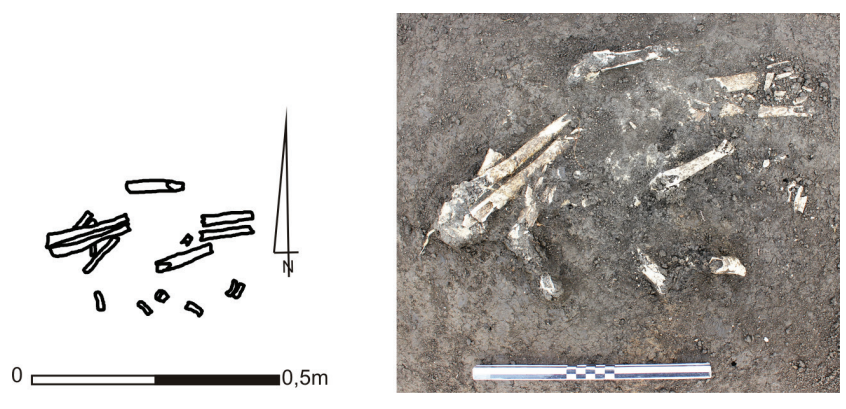

Fig. 16. Klembivka, Yampil Region, barrow 1, feature 1/9. Horizontal projection of feature

A cluster of sheep/goat bones (ends of limbs, ribs and teeth) located underneath the mound at the eastern barrow edge. At the bones, a fragment of the lip of a Tripolye culture vessel was discovered (Fig. 16).

Feature $1 / 10$

\begin{tabular}{|c|c|c|c|}
\hline Culture & \multicolumn{3}{|l|}{ Babyno? } \\
\hline \multicolumn{4}{|l|}{ Dating } \\
\hline \multicolumn{2}{|l|}{ Grave pit } & \multicolumn{2}{|l|}{ Burial } \\
\hline Structure type & Pit & Sex & $?$ \\
\hline Number of burials & $?$ & Age & $?$ \\
\hline $\begin{array}{l}\text { Size at the level } \\
\text { of discovery }\end{array}$ & $?$ & Orientation & $?$ \\
\hline $\begin{array}{l}\text { Size at the level } \\
\text { of the bottom }\end{array}$ & $0.8 \times 0.5 \mathrm{~m}$ & Deviation & $?$ \\
\hline Depth & $1.05 \mathrm{~m}$ & Arrangement of head & $?$ \\
\hline Pit orientation & $\mathrm{S}-\mathrm{N}$ & Arrangement of trunk & $?$ \\
\hline Deviation & $11^{\circ} \mathrm{W}$ & Upper limbs & $?$ \\
\hline $\begin{array}{l}\text { Distance from barrow } \\
\text { centre }\end{array}$ & $6.87 \mathrm{~m}$ & Lower limbs & $?$ \\
\hline Azimuth & $235^{\circ}$ & Ochre & - \\
\hline Wooden roofing & - & Presence of mat & - \\
\hline $\begin{array}{l}\text { Roofing element } \\
\text { orientation }\end{array}$ & & Animal bones & - \\
\hline $\begin{array}{l}\text { Other structural } \\
\text { elements }\end{array}$ & $\begin{array}{l}\text { Grave cover of stone } \\
\text { slabs }\end{array}$ & Ritual objects & - \\
\hline Comments & \multicolumn{3}{|c|}{ Secondarily disturbed gave? } \\
\hline
\end{tabular}

A pit grave (?) sunk into the western portion of the mound. A rectangular pit held in the middle of its fill many lime stones. On the bottom, no bones of a burial were discovered (Fig. 17). 


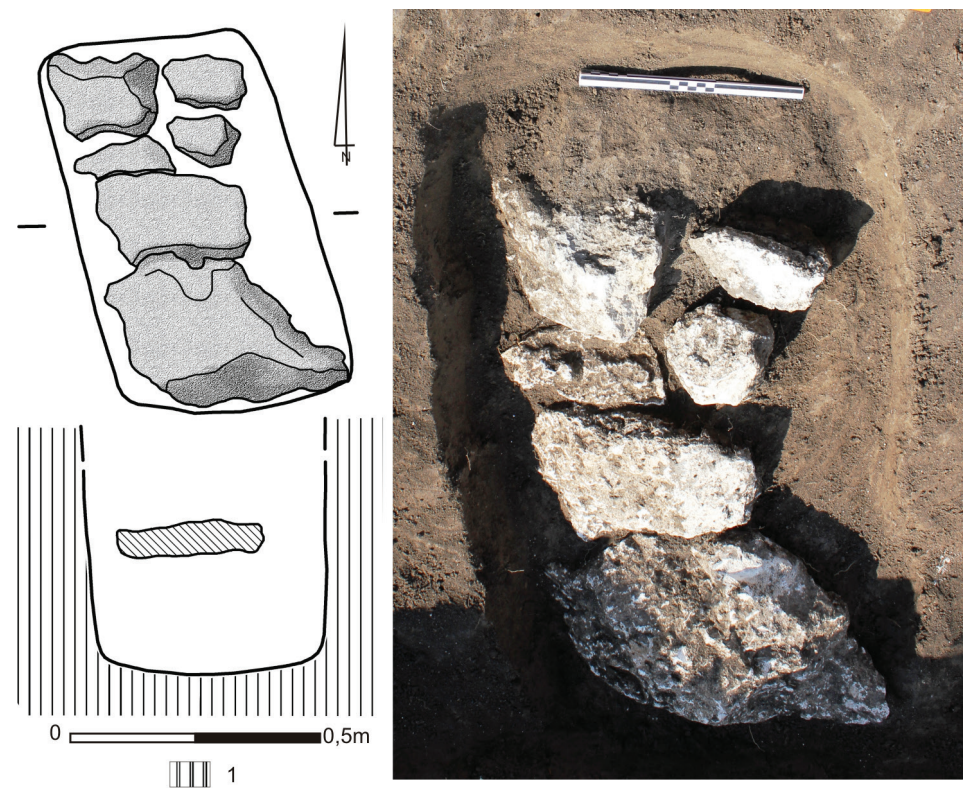

Fig. 17. Klembivka, Yampil Region, barrow 1, feature 1/10. Horizontal and vertical projections of feature. 1 - barrow mound

Feature 1/11

\begin{tabular}{|c|c|c|c|}
\hline Culture & \multicolumn{3}{|l|}{ Noua } \\
\hline Dating & \multicolumn{3}{|c|}{ Poz-70672 $4370 \pm 40$ BP; BIS Poz-72043 $4345 \pm 35$ BP (human bones) } \\
\hline \multicolumn{2}{|l|}{ Grave pit } & \multicolumn{2}{|c|}{ Burial } \\
\hline Structure type & Pit & Sex & Male \\
\hline Number of burials & 1 & Age & below 25 years \\
\hline $\begin{array}{l}\text { Size at the level } \\
\text { of discovery }\end{array}$ & $?$ & Orientation & NE-SW \\
\hline $\begin{array}{l}\text { Size at the level } \\
\text { of the bottom }\end{array}$ & $1.8 \times 0.9 \mathrm{~m}$ & Deviation & $0^{\circ}$ \\
\hline Depth & $1.1 \mathrm{~m}$ & Arrangement of head & $\mathrm{L}$ \\
\hline Pit orientation & NE-SW & Arrangement of trunk & Supine \\
\hline Deviation & $6^{\circ} \mathrm{W}$ & Upper limbs & $\mathrm{B}$ \\
\hline $\begin{array}{l}\text { Distance from barrow } \\
\text { centre }\end{array}$ & $20.75 \mathrm{~m}$ & Lower limbs & 7 \\
\hline Azimuth & $144^{\circ}$ & Ochre & - \\
\hline Wooden roofing & - & Presence of mat & - \\
\hline $\begin{array}{l}\text { Roofing element } \\
\text { orientation }\end{array}$ & & Animal bones & - \\
\hline
\end{tabular}




\begin{tabular}{|l|l|l|l|}
\hline $\begin{array}{l}\text { Other structural } \\
\text { elements }\end{array}$ & - & Ritual objects & Vessel \\
\hline Comments & \multicolumn{2}{|l|}{} \\
\hline
\end{tabular}

The grave was sunk into the barrow ditch at the southern edge of the mound. On the bottom of a rectangular pit, the skeleton of an adult male lay supine, turned to its left side. Next to the deceased, close to the pelvis, a vessel was found. In addition, in the northern portion of the pit, a discovery was made of charred wood remains $0.3 \mathrm{~m}$ long (Figs. 18, 19).
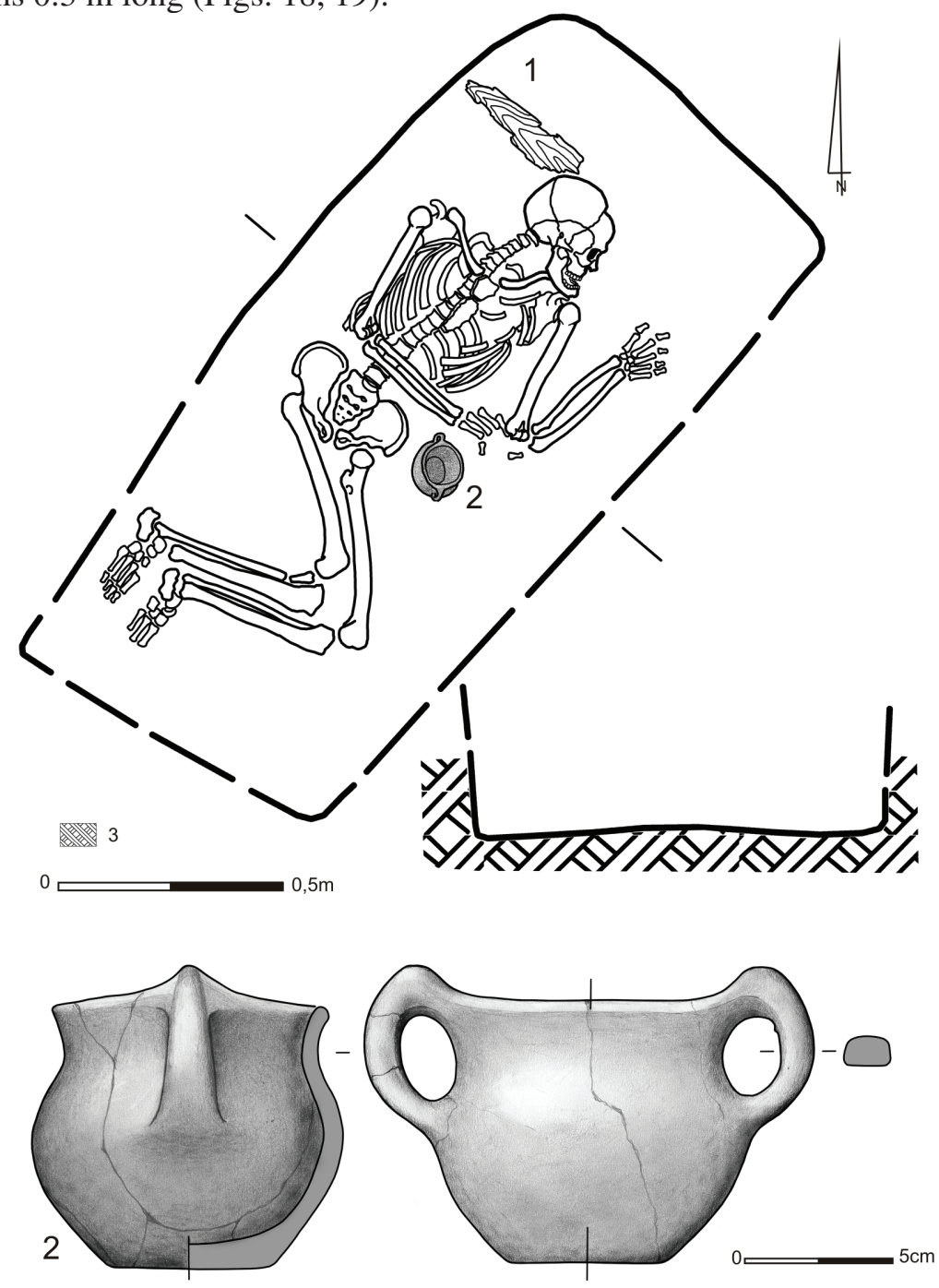

Fig. 18. Klembivka, Yampil Region, barrow 1, feature 1/11. Horizontal and vertical projections of feature. 1 - wood remains; 2 - ceramic vessel; 3 - yellow loess 


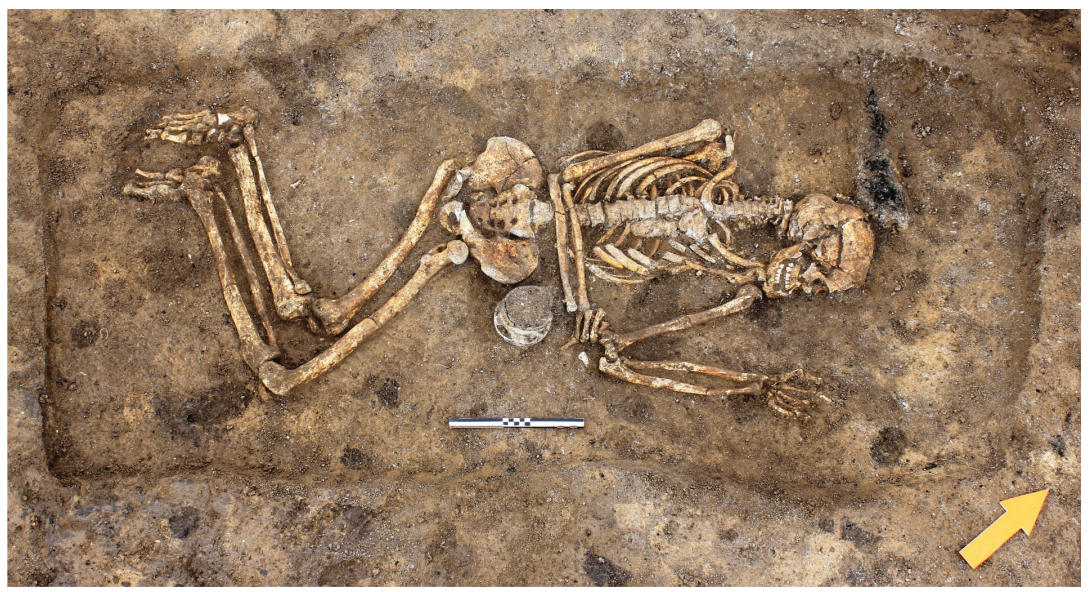

Fig. 19. Klembivka, Yampil Region, barrow 1, feature 1/11. Horizontal projection of burial

\section{Inventory}

1. A small vase-like vessel with two ribbon, 'stretched upwards' handles. The lip rim is slightly flattened. The bottom is flat. The ceramic body contains temper of crushed stones and sand. The outer surface is grey and brown in colour, even and slipped. Dimensions: height $-9.0 \mathrm{~cm}$ (together with handles $-10.0 \mathrm{~cm}$ ), mouth diameter $-9.5 \mathrm{~cm}$, belly diameter $-10.4 \mathrm{~cm}$, bottom diameter $-5.5 \mathrm{~cm}$, wall thickness $-0.5-0.7 \mathrm{~cm}$ (Fig. 18: 2).

\section{Feature $1 / 12$}

\begin{tabular}{|c|c|c|c|}
\hline Culture & \multicolumn{3}{|l|}{ Babyno } \\
\hline Dating & \multicolumn{3}{|c|}{ Poz-74400 $3645 \pm 35$ BP (human bone) } \\
\hline \multicolumn{2}{|l|}{ Grave pit } & \multicolumn{2}{|l|}{ Burial } \\
\hline Structure type & Pit & Sex & $?$ \\
\hline Number of burials & 1 & Age & $12-14$ years \\
\hline $\begin{array}{l}\text { Size at the level } \\
\text { of discovery }\end{array}$ & $?$ & Orientation & NE-SW \\
\hline $\begin{array}{l}\text { Size at the level } \\
\text { of the bottom }\end{array}$ & $1.0 \times 0.8 \mathrm{~m}$ & Deviation & $9^{\circ}$ \\
\hline Depth & $1.2 \mathrm{~m}$ & Arrangement of head & $\mathrm{P}$ \\
\hline Pit orientation & $\mathrm{N}-\mathrm{S}$ & Arrangement of trunk & $\mathrm{P}$ \\
\hline Deviation & $0^{\circ}$ & Upper limbs & $\mathrm{D}$ \\
\hline $\begin{array}{l}\text { Distance from barrow } \\
\text { centre }\end{array}$ & $23 \mathrm{~m}$ & Lower limbs & $5 / 1$ \\
\hline Azimuth & $181^{\circ}$ & Ochre & - \\
\hline Wooden roofing & - & Presence of mat & - \\
\hline
\end{tabular}




\begin{tabular}{|l|l|l|l|}
\hline $\begin{array}{l}\text { Roofing element } \\
\text { orientation }\end{array}$ & Animal bones & - \\
\hline $\begin{array}{l}\text { Other structural } \\
\text { elements }\end{array}$ & $\begin{array}{l}\text { Wall lining or roofing } \\
\text { of lime stones }\end{array}$ & Ritual objects & - \\
\hline Comments & \multicolumn{2}{|l|}{} \\
\hline
\end{tabular}

The grave was sunk into the barrow ditch at the southern edge of the mound. A rectangular pit contained in its fill a pile of lime stones at a depth of 0.65$-1.05 \mathrm{~m}$. Underneath it, on the pit bottom the skeleton of a child lay crouched on the right side (Figs. 20, 21).

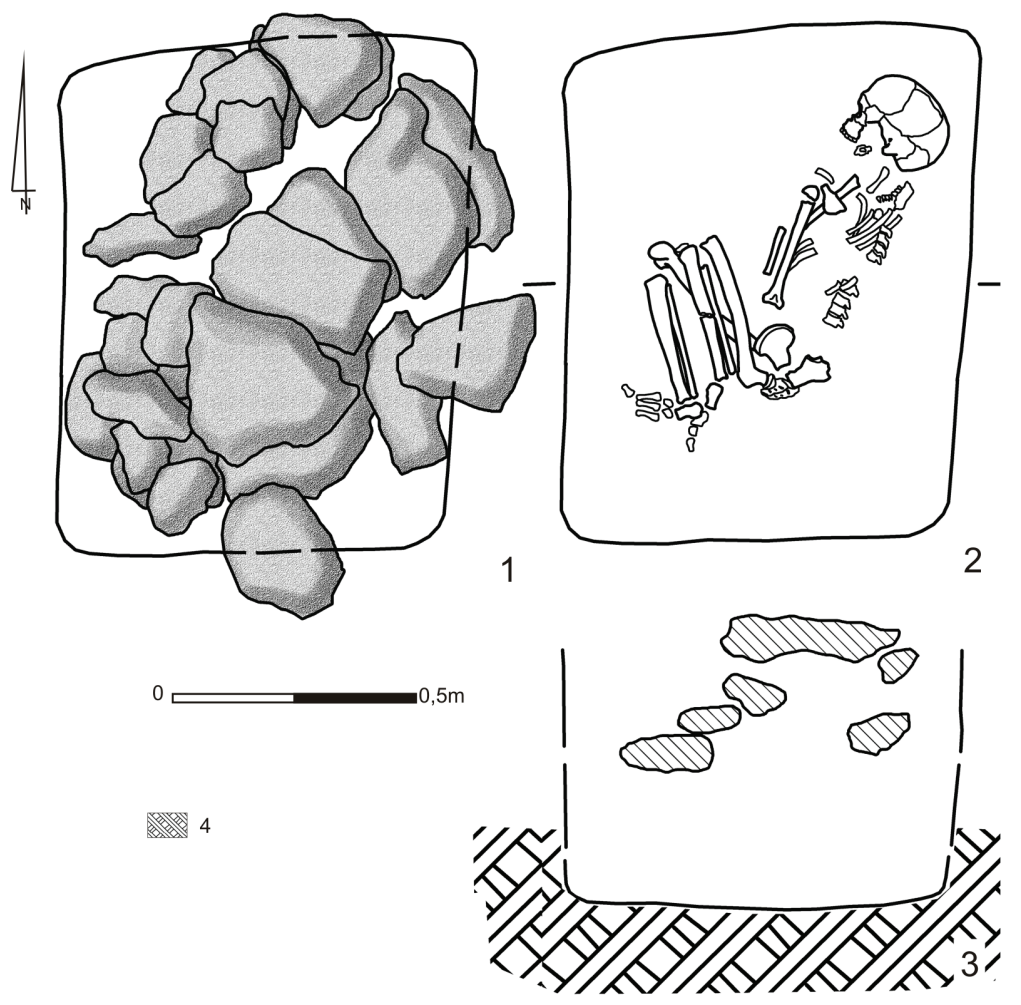

Fig. 20. Klembivka, Yampil Region, barrow 1, feature 1/12. 1 - horizontal projection of feature ceiling; 2 - horizontal projection of feature floor; 3 - vertical projection of feature; 4 - yellow loess 


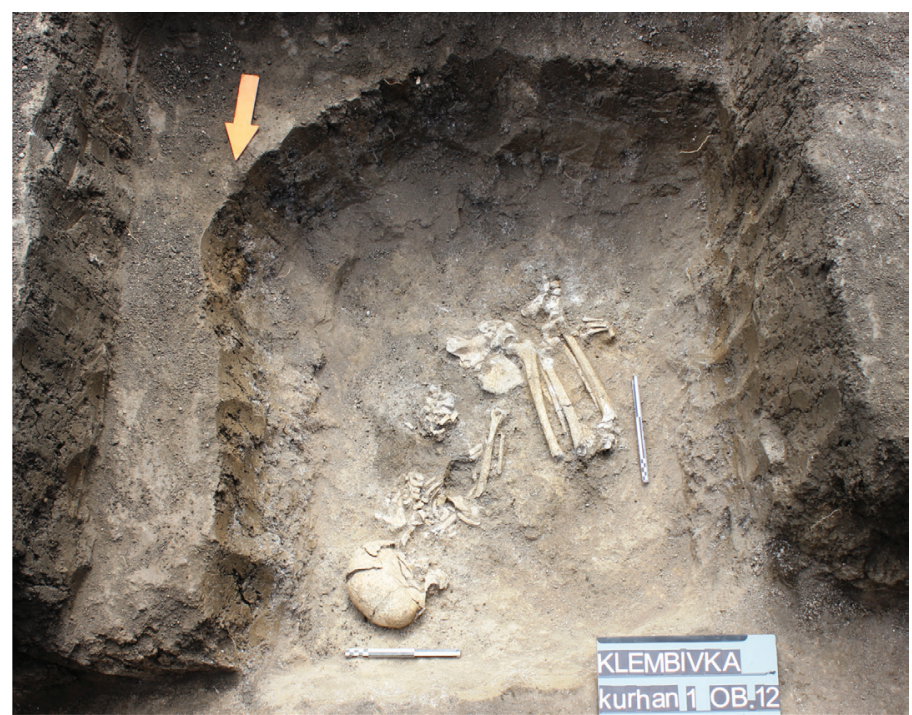

Fig. 21. Klembivka, Yampil Region, barrow 1, feature 1/12. Projection of burial level

Feature 1/13

\begin{tabular}{|l|l|l|l|}
\hline \multicolumn{2}{|l|}{ Culture } & \multicolumn{2}{l|}{ Noua? } \\
\hline Dating & \multicolumn{2}{l|}{ Burial } \\
\hline Grave pit & Pit & Sex & $?$ \\
\hline Structure type & 1 & Age & Adult \\
\hline Number of burials & - & Orientation & N-S? \\
\hline $\begin{array}{l}\text { Size at the level } \\
\text { of discovery }\end{array}$ & $1.15 \times 1.0 \mathrm{~m}$ & Deviation & $?$ \\
\hline $\begin{array}{l}\text { Size at the level } \\
\text { of the bottom }\end{array}$ & $1.45 \mathrm{~m}$ & Arrangement of head & $?$ \\
\hline Depth & N-S & Arrangement of trunk & Supine? \\
\hline Pit orientation & $13^{\circ} \mathrm{E}$ & Upper limbs & $?$ \\
\hline Deviation & $0 \mathrm{~m}$ & Lower limbs & $2 ?$ \\
\hline $\begin{array}{l}\text { Distance from barrow } \\
\text { centre }\end{array}$ & $0^{\circ}$ & Ochre & - \\
\hline Azimuth & - & Presence of mat & + \\
\hline Wooden roofing & Animal bones & - \\
\hline $\begin{array}{l}\text { Roofing element } \\
\text { orientation }\end{array}$ & Stone lining & Ritual objects & - \\
\hline $\begin{array}{l}\text { Other structural } \\
\text { elements }\end{array}$ & & & \\
\hline Comments & & & \\
\hline
\end{tabular}




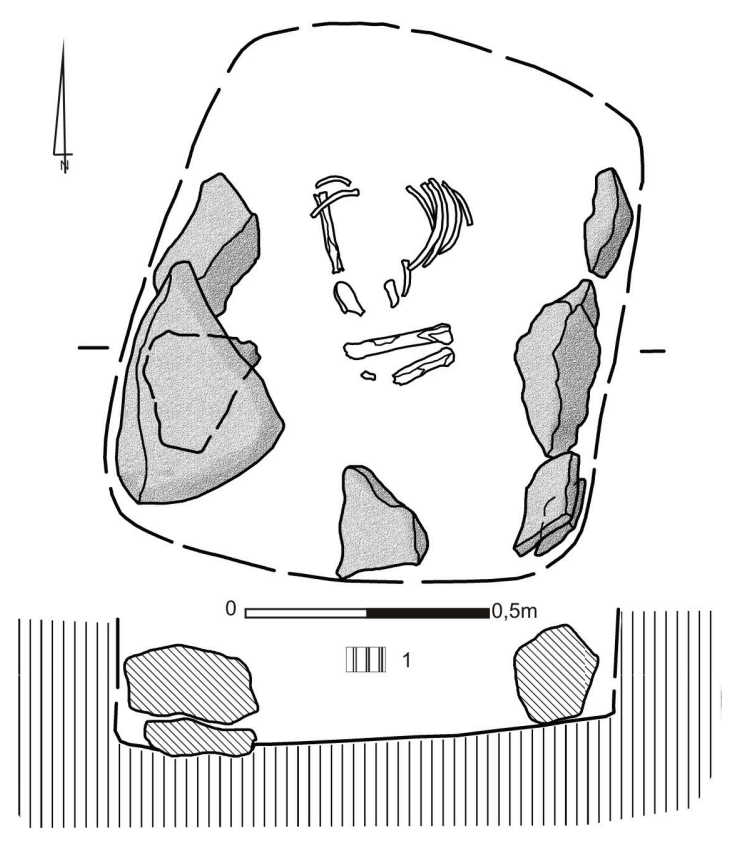

Fig. 22 . Klembivka, Yampil Region, barrow 1, feature 1/13. Horizontal and vertical projections of feature. 1 - barrow mound

The grave was sunk into the central portion of the barrow. Immediately below the floor of surface soil, a pile of lime stones was exposed that originally formed a cist stone-lining. The pit was subrectangular and had rounded corners. On its bottom, the remains of the skeleton of an adult individual were discovered lying crouched on the left side with the head pointing $\mathrm{N}$. Three fragments of long bones bore notches made with a sharp tool (Fig. 22). 
Feature $1 / 14$

\begin{tabular}{|c|c|c|c|}
\hline Culture & \multicolumn{3}{|l|}{ Eneolithic? } \\
\hline Dating & \multicolumn{3}{|c|}{$\begin{array}{l}\text { Poz-52422 } 4330 \pm 50 \text { BP (wood); } \\
\text { Poz-52605 } 4135 \pm 35 \text { BP (human bone) }\end{array}$} \\
\hline \multicolumn{2}{|l|}{ Grave pit } & \multicolumn{2}{|l|}{ Burial } \\
\hline Structure type & Pit & Sex & Male \\
\hline Number of burials & 1 & Age & $25-30$ years \\
\hline $\begin{array}{l}\text { Size at the level } \\
\text { of discovery }\end{array}$ & $2.05 \times 1.95 \mathrm{~m}$ & Orientation & NW-SE \\
\hline $\begin{array}{l}\text { Size at the level } \\
\text { of the bottom }\end{array}$ & $1.2 \times 1.0 \mathrm{~m}$ & Deviation & $8^{\circ} \mathrm{W}$ \\
\hline Depth & $3.0 \mathrm{~m}$ & Arrangement of head & $\mathrm{L}$ \\
\hline Pit orientation & NW-SE & Arrangement of trunk & $\mathrm{L}$ \\
\hline Deviation & $16^{\circ} \mathrm{E}$ & Upper limbs & $\mathrm{D}$ \\
\hline $\begin{array}{l}\text { Distance from barrow } \\
\text { centre }\end{array}$ & $5.15 \mathrm{~m}$ & Lower limbs & $5 / 4$ \\
\hline Azimuth & $143^{\circ}$ & Ochre & + \\
\hline Wooden roofing & $\begin{array}{l}\text { Wood fragments in } \\
\text { the fill }\end{array}$ & Presence of mat & + \\
\hline $\begin{array}{l}\text { Roofing element } \\
\text { orientation }\end{array}$ & $?$ & Animal bones & - \\
\hline $\begin{array}{l}\text { Other structural } \\
\text { elements }\end{array}$ & - & Ritual objects & Flint flake \\
\hline Comments & & & \\
\hline
\end{tabular}

This was the central grave of the younger mound. Its pit was rectangular, almost square in shape. Around its northern portion, at a depth of 1.8-1.9 m, there ran a step $0.15-0.3 \mathrm{~m}$ wide and $0.4 \mathrm{~m}$ below it, a groove was carved in the walls $(0.05 \mathrm{~m}$ deep) to hold the wooden elements of roofing (the fragments of which were discovered at lower levels). On the bottom, the skeleton of an adult male lay contracted on the left side. All bones were coloured with bright red ochre. The occipital bone and the right parietal bone had an irregular hole resulting from a blow (which must have caused the individual's death). Among the ribs, a small flint flake was found (Figs. 23, 24).

Inventory

1. Flake of dark grey Dniester flint. 


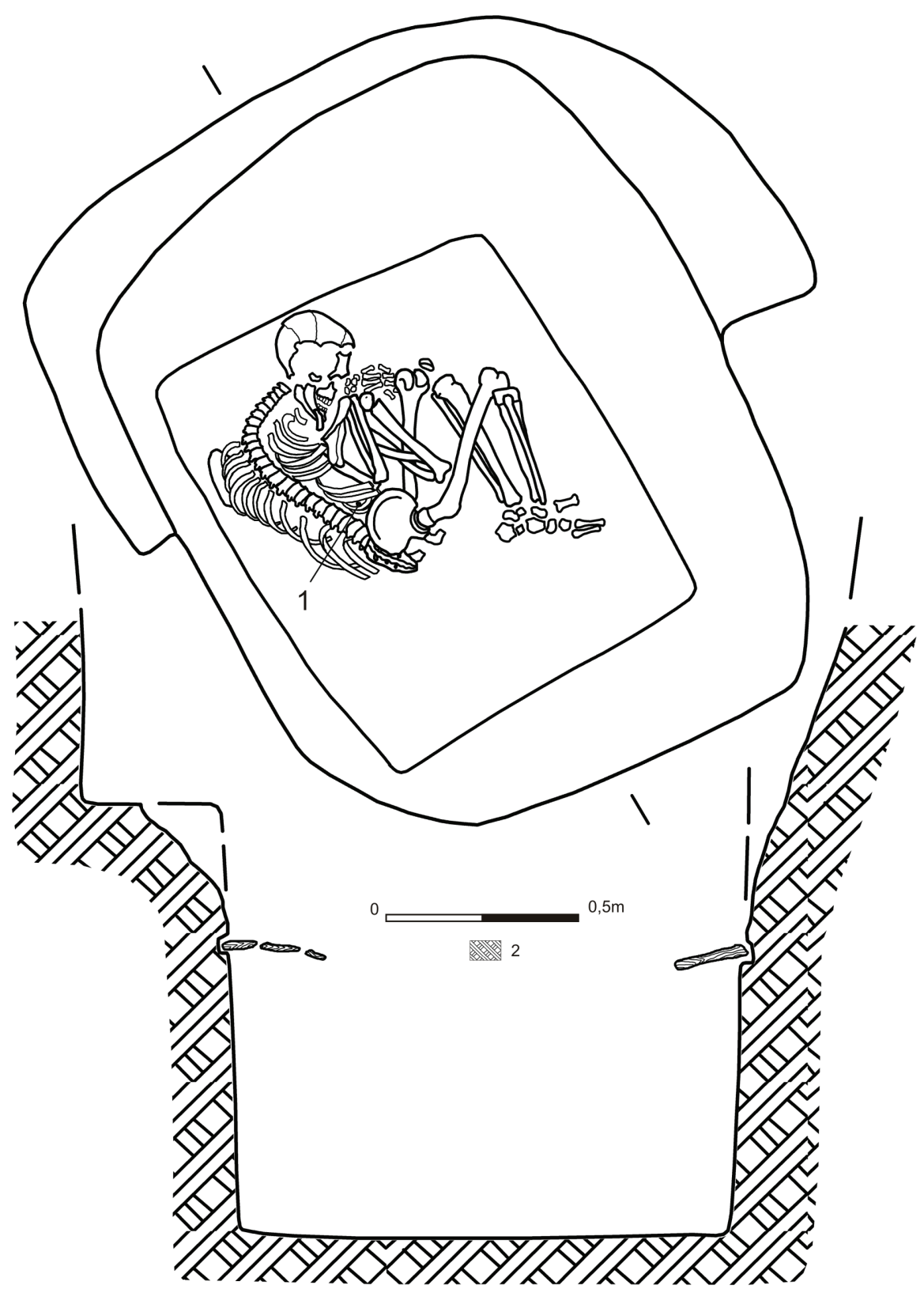

Fig. 23. Klembivka, Yampil Region, barrow 1, feature 1/14. Horizontal and vertical projections of feature. 1 - flint flake; 2 - yellow loess 


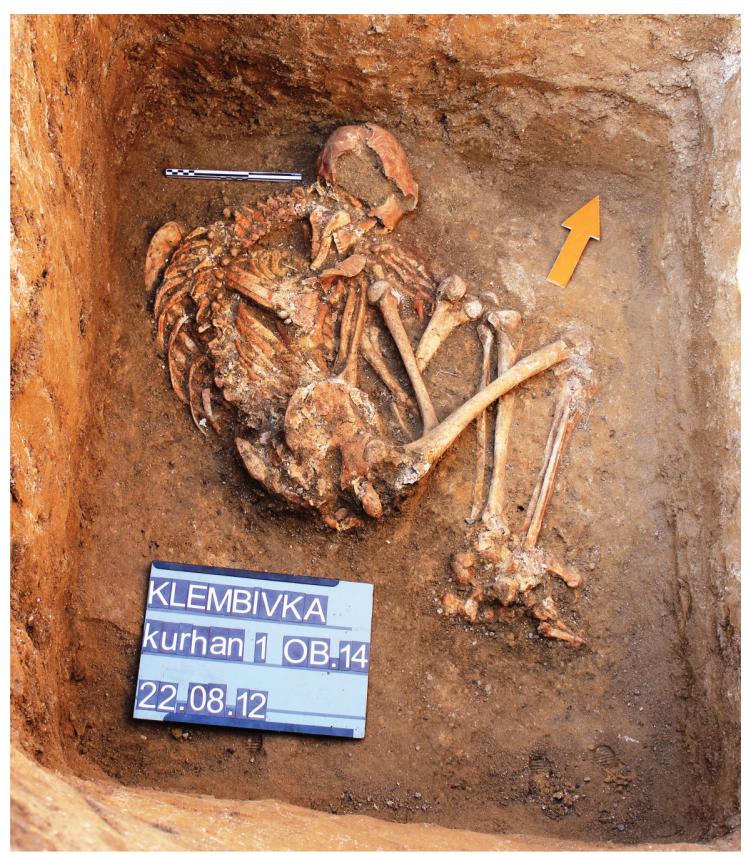

Fig. 24 . Klembivka, Yampil Region, barrow 1, feature 1/14. Horizontal projection of burial level

\section{Feature 1/15}

\begin{tabular}{|l|l|l|l|}
\hline Culture & \multicolumn{2}{|l|}{ Eneolithic? } \\
\hline Dating & \multicolumn{2}{l|}{ Poz77470: 4290 \pm 35 BP (human bone) } \\
\hline Grave pit & Pit & Burial \\
\hline Structure type & Sex & $?$ \\
\hline Number of burials & 1 & Age & $15-20$ years \\
\hline $\begin{array}{l}\text { Size at the level } \\
\text { of discovery }\end{array}$ & $1.8 \times 1.2 \mathrm{~m}$ & Orientation & NW-SE \\
\hline $\begin{array}{l}\text { Size at the level } \\
\text { of the bottom }\end{array}$ & $1.9 \times 0.9 \mathrm{~m}$ & Deviation & $0^{\circ}$ \\
\hline Depth & $1.55 \mathrm{~m}$ & Arrangement of head & $?$ \\
\hline Pit orientation & NW-SW & Arrangement of trunk & Supine \\
\hline Deviation & $9^{\circ} \mathrm{E}$ & Upper limbs & F? \\
\hline $\begin{array}{l}\text { Distance from barrow } \\
\text { centre }\end{array}$ & & Lower limbs & $6 ?$ \\
\hline Azimuth & & Ochre & + \\
\hline Wooden roofing & - & Presence of mat & + \\
\hline $\begin{array}{l}\text { Roofing element } \\
\text { orientation }\end{array}$ & & Animal bones & 1 frag. of cow bone \\
\hline
\end{tabular}




\begin{tabular}{|l|l|l|l|}
\hline $\begin{array}{l}\text { Other structural } \\
\text { elements }\end{array}$ & - & Ritual objects & Lump of ochre \\
\hline Comments & \multicolumn{3}{|l|}{} \\
\hline
\end{tabular}

This was the central grave of the older mound. The pit was subrectangular. A poorly-preserved skeleton of a Juvenis individual lay supine, crouched. The remains were disturbed by many animal burrows. At the left shoulder, the traces of a decayed lump of red ochre were discovered (Figs. 25, 26).

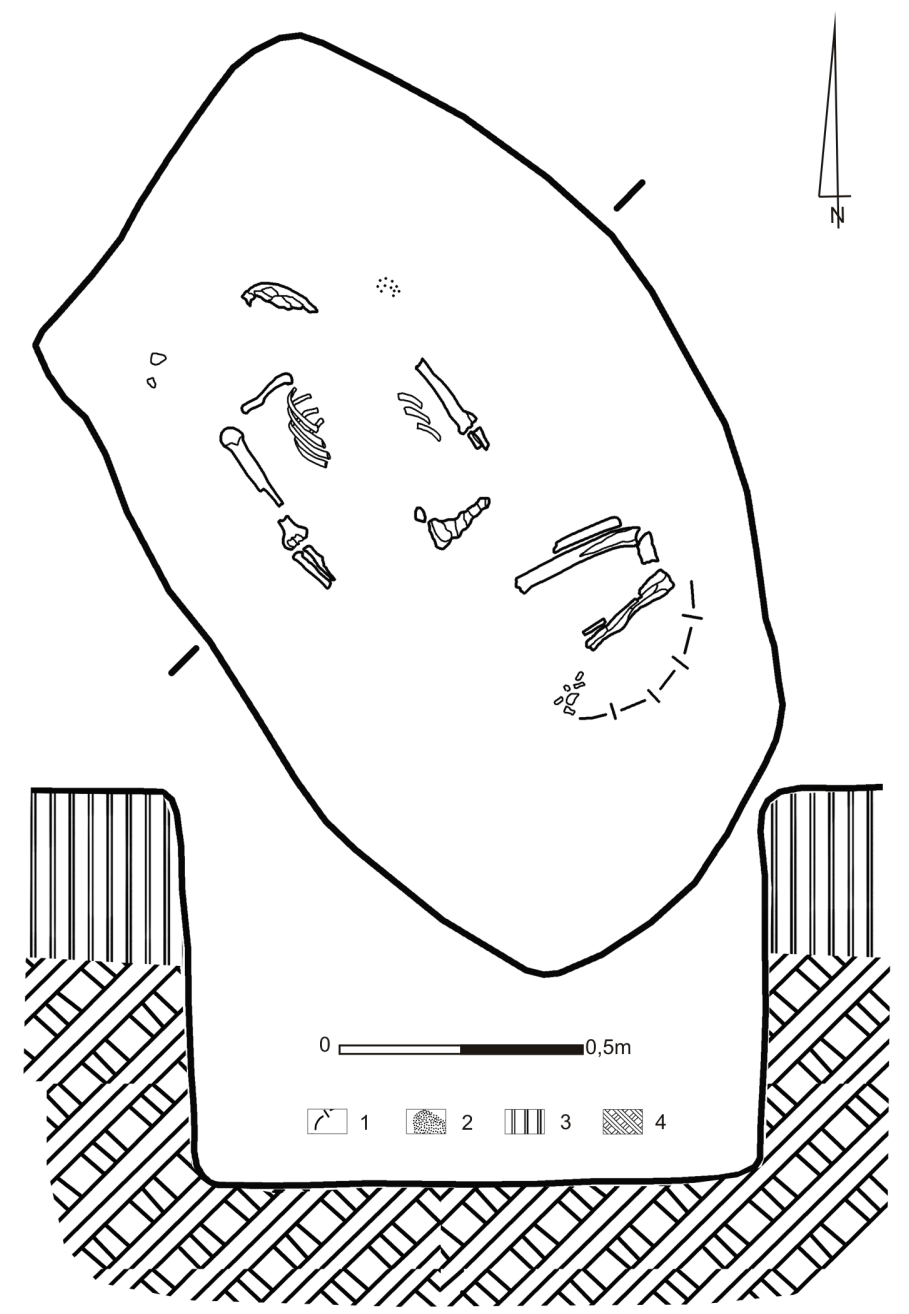

Fig. 25. Klembivka, Yampil Region, barrow 1, feature 1/15. Horizontal and vertical projections of feature. 1 - mat outline; 2 - ochre; 3 - original ground level; 4 - yellow loess 


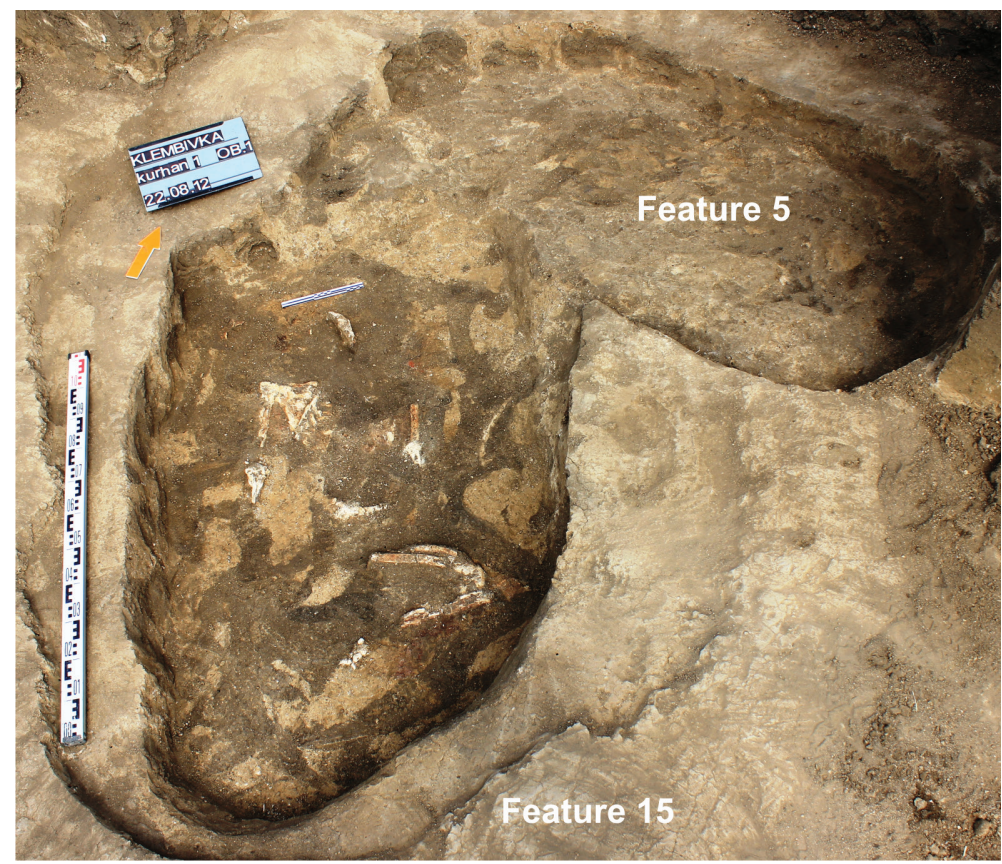

Fig. 26. Klembivka, Yampil Region, barrow 1, feature 1/15. Horizontal projection of burial in relation to neighbouring feature $1 / 5$

Finds from the mound

On the south-eastern edge of the older mound, at a depth of about $0.6 \mathrm{~m}$ (or on the original ground level), an anthropomorphic stela made from a lime slab measuring $0.7 \times 0.7 \times 0.10 \mathrm{~m}$ was exposed (Fig. 6).

Moreover, in two places, animal bones were found, possibly linked to sacrificial deposits made at the mound construction. A bone of a domesticated horse was found at the eastern edge of the younger mound, while at the eastern edge of the older mound, a bone of a small ruminant was discovered.

\section{RADIOCARBON CHRONOMETRY}

Radiocarbon age determinations of 10 samples were performed at the Poznań Radiocarbon Laboratory, Adam Mickiewicz University Foundation, Poznań, Po- 
land. Nine samples of bones and one of charcoal were taken from eight features ( 1 , $3,5,7,11,12,14$ and 15$)$.

In eight cases, the determinations were consistent with archaeological expectations whereas in two, they were widely discrepant (feature $1 / 11=$ archaeometric or possibly laboratory error). A full description of chronometric foundations useful in the reconstruction of the cemetery use can be found in the paper on the Yampil chronometric scale of the 4th/3rd-2nd millennium BC [Goslar et al. 2015].

Relying on the determinations and Klembivka taxonomic observations, it can be justifiably claimed that the site in question, viewed as part of the Klembivka ceremonial centre, witnessed two stages of ritual activity:

Stage I. The necropolis was laid out in the 30th-28th century BC (3005$-2720 \mathrm{BC}$ - features 1/14 and 1/15) as the burial place of Eneolithic communities (or possibly 'Eneolithic or Early Bronze' ones, i.e. occupying a borderline taxonomic position, see Ch. 4) and was probably continuously used until the 29th-28th century BC (2900-2760 BC - feature 1/5, linked to the Eneolithic or Early Catacomb/'Yamnaya-Catacomb' communities).

Stage II. Until the late 21 st and early 20th centuries BC (2117-1952 BC - feature 1/12), when a successive burial, taxonomically debatable (probably connected to the BC), was deposited here, that is for about 700/600 years, no signs of funerary connections can be seen in relation to the 'Eneolithic-Early Bronze' ceremonial traditions of the 'cemetery hill' mentioned earlier. Successive burials were deposited in this place by:

- $\quad$ BC communities in the 19th-18th BC (1880-1771 BC - features $1 / 3$ and $1 / 12)$, and

- a NC population about 500/400 years later, in the 15th-14th century (1443$-1311 \mathrm{BC}$ - feature 1/7).

The 'funerary gaps' mentioned above should be studied against the background of the source potential of the Klembivka barrow cluster which can be estimated to have been explored so far in 20 per cent at best (see Ch. 4).

\section{TAXONOMY OF FUNERARY ARCHITECTURE AND GRAVE} INVENTORIES

It must be remembered that the set of 13 grave features from Klembivka 1, both at the stage of field identification and in the preliminary report, was assigned to the YC (features 1/5, 1/14 and 1/15) and BC (features 1/1 and 1/3), while a large group of features were considered 'Late Bronze'. The latter were graves without any grave goods and as such very hard to identify taxonomically [Razumov et al. 2013]. The 
set is complemented by ritual features identified then as 'Early Bronze' (feature $1 / 4$ - with a bone of a roe deer and 28 other indeterminate animal bones; feature $1 / 9$ - with a fragment of the Tripolye culture (TC) vessel and 11 sheep/goat bones).

Later re-analyses - completed after 2014 - have expanded the cultural-chronological picture of cemetery users to include the $\mathrm{NC}^{2}$. Furthermore, it has been found admissible to link the oldest burials and sacrificial pits - earlier associated with the YC - to the Eneolithic horizon [Ivanova, Toschev 2015; 2015a].

4.1. ENEOLITHIC

Both early barrow features were built over single burials: $1 / 15=$ older mound and $1 / 14=$ younger mound. The two barrows differ in size and shape at the ground level. The older one, connected to grave $1 / 15$, is oval in shape, its maximum diameter is $24.0 \mathrm{~m}$ and is $0.5-0.7 \mathrm{~m}$ high, while the younger one, raised over grave $1 / 14$, is circular in shape, up to $30.0 \mathrm{~m}$ in diameter and its original height is estimated at about $3.0 \mathrm{~m}$. Both features are chronometrically close, fitting into the time bracket of 3005-2720 BC [Goslar et al. 2015], i.e. the time when the YC early rite was identified on Prydnistryanske 1 (3063-2682 BC) [Klochko et al. 2015]. The problem remains that this is also the time of the hypothetical coexistence of the decline TC, steppe Eneolithic groups and the early YC in the area of the Yampil barrow cluster. A symbolic manifestation of this identification-taxonomic problem is ritual feature 1/9 in which a fragment of TC pottery was found. Given the situation, the funerary architecture of both graves is crucial.

Burial 1/15 - connected to the older mound - was deposited in a rather irregular, subrectangular pit. The deceased lay supine on a mat with the lower limbs crouched and upper limbs probably extended along the body (subtype IIA according to Y.Y. Rassmakin [2004]). At the head, a lump of ochre was placed. This rite is characteristic of the early YC [Klochko et al. 2015]. However, it is not alien, either, to Eneolithic rites. In right-bank Ukraine, these traits are characteristic of the post-Stog group of burials [Rassamakin, Evdokimov 2002; Rassamakin 2013: $117,120]$. Characteristic of this group, oval grave pits are accompanied in the late phase by sub-rectangular excavations analogously to the case of Klembivka 1/15 [Ivanova 2015: 282, 283]. This rite is also close to the model found in the beginnings of the Bronze Age, which, incidentally, makes individual researchers differ in assigning 'late Stog type' burials either to the Eneolithic or the early phase of the YC. A similar case is encountered with Repin culture burials in left-bank Ukraine [Rassamakin 2013: 117].

\footnotetext{
${ }^{2}$ Opinions supported by Prof. V.I. Klochko and Dr. G.N. Toschev.
} 
The stone stela - on account of its location - must have been connected to the older mound (only later was it covered by the strata of the younger mound). In the opinion of E.V. Yarovoy, most anthropomorphic stelae and stone slabs from between the Dniester and Danube rivers are linked to the cult-funeral structures of Eneolithic communities, while in later periods (especially in the Early Bronze Age, i.e. by YC populations), they were destroyed, moved and re-used for other purposes (mainly as elements of grave structures) [Yarovoy 2001: 71-73].

Additionally, in favour of connecting the older Klembivka barrow structure to the Eneolithic rite, ritual animal bone deposits speak which were made prior to mound building. In particular, feature 1/4 - having the parameters of a large post hole - finds analogies in other Eneolithic barrows, including Podolia features from Porohy (barrow 3A) [Klochko et al. 2015b] and Mocra (barrow 1) [Kashuba et al. 2001-2002: 220]. Such remains of peri-funeral rites performed prior to mound building and recorded now on the ground surface are mostly a sign of the pre-Yamnaya age of a barrow [Rassamakin 2013: 130].

The pit structure and arrangement of the deceased in grave 1/15 from Klembivka find a good analogy in feature 1/1B from Pidlisivka - the central burial connected to the building of the older mound [Klochko et al.2015a]. Both barrows seem to represent the same, Late Eneolithic tradition. In both cases, too, after a short time, into the central portion of the barrow, another feature was sunk, which initiated the extension of the barrow.

Feature 1/14 from Klembivka significantly departs from the model identified with the early YC stage, in particular, in terms of the arrangement of the deceased (contracted on the left side, with hands directed towards the face). This arrangement type - subtype IIIC according to Y.Y. Rassmakin [2004: 55-59] - is encountered in Eneolithic cemeteries in the Dniester-Danube Region. It is also known from the steppe-community barrows of the Zhyvotilovka-Volchansk type [e.g. Bursuceni, graves 8, 20, 21 and 25, or Taraclia 1, barrow 1] [Yarovoy 1978; Dergachev 1991: Fig. 42: 12,13], as well as an undetermined variety pointing to connections to Ciscaucasia (Costeşti, grave 2/1) [Dergachev 1982: 9, Fig. 2: 11]. This corpse arrangement is also often found in Late Tripolye cemeteries of the Vykhvatyntsi and Usatovo types, both flat and barrow ones [Dergachev 1991: Fig. 14-89]. In contrast, on the Podolia Upland, the burial type found in grave 1/14 is a single occurrence. It may be related to a community representing a cultural tradition other than that shared by the builders of the older mound. The radiocarbon dating obtained for the bones from this feature (Poz-52605: $4135 \pm 35 \mathrm{BP}$ ) is consistent with the results obtained for 'classic' YC burials in the Yampil area [Goslar et al. 2015]. For this reason, it seems the best solution to consider this grave a case of reminiscence of older Eneolithic traditions in the Early Bronze Age [Ivanova 2015: 285-286].

Located in the central portion of the barrow, feature $1 / 5$ was a pit grave, irregular in shape, subrectangular, resembling the outline of feature $1 / 15$. It was most 
probably sunk into the mound of the older barrow (a certain reconstruction is prevented by the degree of barrow levelling off) and its floor part reached the ceiling level of yellow loess (it was located only slightly higher than the level of feature 1/15). On this account, it is believed that grave 5 is linked to the Late Eneolithic horizon. This belief is supported by the result of radiocarbon dating as well - close to the result obtained for grave $1 / 15$.

The arrangement of the deceased in graves $1 / 5$ and 1/15 was similar as well: they lay supine with the lower limbs turned to the left side. What differed them from others was probably the arrangement of upper limbs (only vestiges are left in the case of feature 1/15 - which prevents a certain reconstruction) and the presence of an ochre lump and a mat lining the pit bottom in the central grave. Considering the similarities, both graves may be combined into a single tradition and a conjecture may be made about their creation in a narrow time bracket (which is borne out by radiocarbon age determinations).

The arrangement of the deceased in feature $1 / 5$ resembles that recorded in feature 1/7 from Pidlisivka, having the nature of a catacomb or a semi-niche. The latter feature has been thought to have been linked to the Early Catacomb horizon [Klochko et al. 2015a]. However, the 'Catacomb traditions' of constructing grave excavations appeared as early as in the Late Eneolithic in Podolia [Prydnistryanske 1, grave IV/10: 3355-3176 BC, or Bylshivtsi, Ki-8272: 3695-3370 BC - Goslar et al. 2015; Tkachuk 2001-2002: 214, Fig. 21], as in the entire Northern Pontic Area [Rassamakin 2004: 43, 57, 58]. They may have been continued in the YC rites already from the outset of the 3rd millennium BC. This is excellently illustrated by feature $1 / 5$ from Klembivka 1 , of direct interest to us here. It is close to the 'taxonomic borderline' of the Eneolithic (traditions of the TC - probably of the Gordineşti group, see feature 9) and the early YC (2900-2760 BC - Ch. 3).

Considering the Yampil graves cited above and a territorially close CC grave from Okniţsa 3 [Klochko 1990], one can attempt to distinguish an early horizon of the Catacomb funerary rite in forest-steppe Podolia. The horizon is hardly identifiable for the time being when only archaeometric 'field' data is available. This is also borne out by the experience of investigating Podolia sites: Pidlisivka 1 (graves $1 / 4$ and 1/7) and Klembivka 1 (grave 1/5), as well as Kuzmin (grave 2/5) [Bubulich, Khakheu 2002: 132].

In the studies of neighbouring lands - in relation to the Yampil concentration of early Catacomb traits - where syncretic, 'Yamnaya-Catacomb' ritual behaviour was recorded, a dominant conception has held so far that they corresponded to the 'late YC phases'. They concerned the steppe portion of the Southern Bug (Boh) River [Fomenko 1999 - 'features of a Yamnaya-Catacomb mixed type'] or the Dniester-Prut interfluve [Ivanova, Toschev 2015; 2015a]. Similar conclusions can be drawn, too, from the updating of the discussion on the share of 'Catacomb' traditions in the rise of the Yampil barrow cluster, inspired by their recently published monograph [Ivanova 2014; Harat, et al. 2014]. Polemical comments concerned 
a feature considered a BC grave (Severynivka 1/4), ignoring, however, the question of its more detailed taxonomic identification [Ivanova et al. 2015].

Thus, a more active presence of the CC in the left-bank Dniester Area should be credibly dated to the middle of the 3rd millennium BC. This estimate follows from both typo-chronological findings and the directly dated feature/grave I/4 from Prydnistryanske 1 (a grave showing affinities with the traditions of the "classic CC stage'): 2600-2450 BC [Goslar et al. 2015]. This date corroborates one of the suggested variant chronological brackets of the $\mathrm{CC}$ in the Dniester-Prut interfluve: 2450-1950 BC [Kaiser 2003] or 2600-2200 BC [Ivanova 2014: 22; Ivanova, Toschev 2015a].

4.2. LATE BRONZE AGE: BABYNO AND NOUA CULTURES

The Klembivka barrow clearly demonstrates the characteristic traits of Late Bronze burials in the region under investigation conventionally assigned to the $\mathrm{BC}$ (features 1,2,3 and 12) and NC (features 7, 11 and 13-?). Without grave goods and ${ }^{14} \mathrm{C}$ dates, they are often hard to distinguish. This circumstance, no doubt, bears out the opinion shared by almost all researchers studying the NC about the participation of the local BC variety (Mnogovalikovaya Pottery culture) in the formation of the NC. In the Klembivka barrow, a rare case of a mixed, BC and NC flat cemetery 'crawling' onto a barrow chronologically straddling the Eneolithic and Early Bronze Age was recorded.

5. THE POSITION OF KLEMBIVKA 1 CEMETERIES IN THE CULTURAL SPACE OF THE BLACK SEA DRAINAGE BASIN

As already mentioned earlier, the investigated barrow is one of a cluster of five features of similar morphology that were identified on the surface of the ground on the high watershed crest of the Rusava and Korytna rivers (Fig. 2). We assume that a relatively complete sequence of ritual behaviour from the $3 \mathrm{rd}-2 \mathrm{nd}$ millennium $\mathrm{BC}$ may be systemically analysed on the surface of the Klembivka barrow cluster. The relativity of this assessment follows from the limited - up to a maximum of 20 per cent - state of its surface exploration. Moreover, it is worth noting in this context that the cluster occupies a fringe, northernmost position in relation to the Yampil concentration of barrow cemetery complexes [Kośko et al. (Eds) 2014]. 
In terms of site distance from the Dniester valley, the necropolises in Klembivka 1 and Pidlisivka 3A are relatively far 'less on the Dniester' than cemeteries in Prydnistryanske 1 or Porohy 3A. This applies to the 'exposition' of burials from the final period of the Late Eneolithic - i.e. from the beginning of the 3rd millennium BC - with a clearly less marked presence of the 'YC stage' on these two sites. We may be given in this case an important hint as to the interpretation of the autogenesis of the Yampil concentration of barrow cemetery complexes: the first reading of the stages of its chorography.

In the case of the necropolises of the Late Bronze Age, it must be observed that Klembivka (or to put it more broadly 'Yampil') evidence slightly extends to the north the NC area within the left-bank Middle Dniester Area [Krushelnitska 2006]. ***

The general import of the above findings is that the investigations of Klembivka 1 in the first place give support to the thesis about the strong position of the Eneolithic trend in the rise of the Podolia 'barrow architecture' by drawing attention to its long development in parallel with the 'Yamnaya' trend [Klochko et al. 2015a]. Inspiring observations continue to be made by identifying the co-development of both trends far away from the Dniester but close to the watershed between the Dniester and Southern Bug (Boh) rivers.

In the light of this conclusion, major diagnostic significance is acquired by a typically 'watershed barrow cluster' in Severynivka, on the upper Murafa River. Hence, this destination is also worth considering when drawing plans for further desirable research [Klochko, Kośko 2013: Fig. 5]. 


\section{REFERENCES}

Bubulich V.G., Khakheu V.P.

2002 Issledovaniya kurganov v Kamenskom rayone na levoberezhe Srednego Dnestra. In: N.A. Ketraru (Ed.) Severnoe Prichernomore ot eneolita $k$ antichnosti, 112-148. Tiraspol.

Dergachev V.A.

1982 Materialy raskopok arkheologicheskoy ekspeditsii na Srednem Prute (1975-1976 gg.). Kishinev.

Dergachev V.A., Manzura I.V.

1991 Pogrebalnye kompleksy pozdnego Tripolia. Kishinev.

Fomenko V.N.

1999 Ob odnoy gruppe pogrebeniy vremeni katakombnoy kultury v stepnom Pobuzhe. In: O.G. Shaposhnikova, V.V. Otroschenko, S.Z. Pustovalov, G.N. Toschev, G.I. Shapovalov (Eds) Problemy izucheniya katakombnoy kulturno-istoricheskoy obschnosti, 99-101. Zaporozhe.

Goslar T., Klochko V.I., Kośko A., Włodarczak P., Żurkiewicz D.

2015 Chronometry of Late Eneolithic and 'Early Bronze' cultures in the Middle Dniester area: investigations of the Yampil Barrow Complex. In: A. Kośko (Ed.). Podolia as a Cultural Contact Area in the 4th/3rd-2nd Millennium BC. Baltic-Pontic Studies 20: 256-291.

Harat K., Potupczyk M., Razumov S.

2014 Charakterystyka źródeł archeologicznych pozyskanych w latach 1984-1993. In: A. Kośko, M. Potupczyk, S. Razumow (Eds) Naddniestrzańskie kompleksy cmentarzysk kurhanowych społeczności z III i z pierwszej polowy II tysiąclecia BC w okolicach Jampola, obwód winnicki. Z badań nad pótnocno-zachodnia rubieża osadnictwa społeczności kręgu kultur „wczesnobrazowych” strefy pontyjskiej. Badania z lat 1984-2010. Archaeologia Bimaris - Monografie 6, 45-204. Poznań.

Ivanova S.V.

2014 Stan badań nad osadnictwem kultur jamowej i katakumbowej w zlewni dolnego Dniestru. In: Kośko A., Potupczyk M., Razumow S. (Eds) Naddniestrzańskie kompleksy cmentarzysk kurhanowych społeczności z III $i$ z pierwszej polowy II tysiq̨clecia BC w okolicach Jampola, obwód winnicki. Z badań nad pótnocno-zachodniq rubieża osadnictwa społeczności 
kręgu kultur „wczesnobrazowych” strefy pontyjskiej. Badania z lat 1984-2010. Archaeologia Bimaris - Monografie 6, 17-33. Poznań.

2015 Protobudzhakskiy gorizont Severo-Zapadnogo Prichernomoria. Stratum plus 2: 275-294.

Ivanova S.V., Klochko V.I., Kośko A., Szmyt M., Toschev G.N., Włodarczak P.

2015 'Yampil inspirations' in the study of the Dniester cultural contact area at the frontier of Pontic and Baltic drainage basins. In: A. Kośko (Ed.). Podolia as a Cultural Contact Area in the 4th/3rd-2nd Millennium BC. BalticPontic Studies 20: 406-424.

Ivanova S.V., Toschev G.N.

2015 Late Eneolithic and Bronze Age prologue Pontic societies. Forest-steppe Middle Dniester and Prut drainage basins in the 4th/3rd-2nd millennium BC: A history of investigations. In: A. Kośko (Ed.) Podolia as a Cultural Contact Area in the 4th/3rd-2nd Millennium BC. Baltic-Pontic Studies 20: 7-39.

2015a The Middle-Dniester cultural contact area of early metal age societies. The frontier of Pontic and Baltic drainage basin in the 4th/3rd-2nd millenium BC. In: A. Kośko (Ed.) Podolia as a Cultural Contact Area in the 4th/3rd-2nd Millennium BC. Baltic-Pontic Studies 20: 336-405.

Jachimowicz K.

2015 Analiza przestrzenna kurhanów kultury grobów jamowych z okolic Jampola, Ukraina (held in the archives of Adam Mickiewicz University) Poznań.

Kaiser E.

2003 Studien zur Katakombengrabkultur zwischen Dnepr und Prut. Archäologie in Eurasien 14. Mainz.

Kashuba M.T., Kurchatov S.Y., Scherbakova T.A.

2001-2002 Kochevniki na zapadnoy granitse Velikoy stepi (po materialam kurganov u s. Mocra), Stratum plus 4: 180-252.

Klochko E.O.

1990 Redkiy pogrebalnyi kompleks katakombnoy kultury na Srednom Dnestre. In: O.G. Shaposhnikova, V.V. Otroschenko, S.Z. Pustovalov, G.N. Toschev, G.I. Shapovalov (Eds) Problemy izucheniya katakombnoy kulturno-istoricheskoy obschnosti, 28-30. Zaporozhe.

Klochko V.I., Kośko A.

2013 The Baltic Drainage Basin in the Reconstruction of the Mental Map of Central Europe Held in Common by Northern-Pontic Early - Bronze Civili- 
zation Communities: 3200-1600 BC. An outline of the research programme. In: A. Kośko, V.I. Klochko (Eds) The Ingul-Donets Early Bronze Civilization as Springboard for Transmission of Pontic Cultural Patterns to the Baltic Drainage Basin 3200-1750 BC. Baltic-Pontic Studies 18: 9-20.

Klochko V.I., Kośko A., Razumow S.M., Włodarczak P.

2014 Problem dniestrzańsko-wiślańskiego w bałtyckich intruzjach społeczności kultur jamowej i katakumbowej. Zarys aktualnego stanu badań. In: A. Kośko, M. Potupczyk, S. Razumow (Eds) Naddniestrzańskie kompleksy cmentarzysk kurhanowych społeczności z III i z pierwszej polowy II tysiąclecia BC w okolicach Jampola, obwód winnicki. Z badań nad pótnocno-zachodniq rubieża osadnictwa społeczności kręgu kultur „wczesnobrazowych" strefy pontyjskiej. Badania z lat 1984-2010. Archaeologia Bimaris - Monografie 6, 387-398. Poznań.

Klochko V.I., Kośko A., Potupchyk M.V., Włodarczak P., Żurkiewicz D., Ivanova S.V.

2015 Tripolye (Gordineşti group), Yamnaya and Catacomb culture cemeteries, Prydnistryanske, site 1, Yampil Region, Vinnitsa Oblast: an archaeometric and chronometric description and a taxonomic and topogenetic discussion. In: A. Kośko (Ed.) Podolia as a Cultural Contact Area in the 4th/3rd-2nd Millennium BC. Baltic-Pontic Studies 20: 183-255.

Klochko V.I., Kośko A., Razumov S.M., Włodarczak P., Żurkiewicz D.

2015a Eneolithic, Yamnaya, Catacomb and Babyno culture cemeteries, Pidlisivka, barrow 1, Yampil Region, Vinnitsa Oblast: archaeometry, chronometry and taxonomy. In: A. Kośko (Ed.) Podolia as a Cultural Contact Area in the 4th/3rd-2nd Millennium BC. Baltic-Pontic Studies 20: 40-77.

$2015 \mathrm{~b}$ Eneolithic, Yamnaya and Noua culture cemeteries from the first half of the 3rd and the middle of the 2nd millennium BC, Porohy, site 3A, Yampil Region, Vinnitsa Oblast: archaeometric and chronometric description, ritual and taxonomic-topogentic identification. In: A. Kośko (Ed.) Podolia as a Cultural Contact Area in the 4th/3rd-2nd Millennium BC. BalticPontic Studies 20: 78-141.

Kośko A., Potupczyk M., Razumow S. (Eds)

2014 Naddniestrzańskie kompleksy cmentarzysk kurhanowych społeczności z III i zpierwszej polowy II tysiąclecia BC w okolicach Jampola, obwód winnicki. $Z$ badań nad pótnocno-zachodnia rubieża osadnictwa społeczności kręgu kultur „wczesnobrazowych” strefy pontyjskiej. Badania z lat 1984-2010. Archaeologia Bimaris - Monografie 6. Poznań. 
Krushelnitska L.

2006 Kultura Noa na zemliakh Ukrayiny. Lviv.

Litvinova L.V., Łukasik S., Żurkiewicz D., Gwizdała M., Chyleński M., Mamström H., Jakobsson M., Juras A.

2015 Anthropological description of skeletal material from the Dniester Barrow-Cemetery Complex, Yampil Region, Vinnitsa Oblast (Ukraine). In: A. Kośko (Ed.) Podolia as a Cultural Contact Area in the 4th/3rd-2nd Millennium BC. Baltic-Pontic Studies 20: 292-335.

Rassamakin Y.Y.

2004 Die nordpontische Steppe in der Kupferzeit Gräber aus der Mitte des 5. Jts. bis Ende des 4. Jts. v. Chr. Archäologie in Eurasien 17. Mainz.

2013 From the Late Eneolithic period to the Early Bronze Age in the Black Sea steppe: what is the Pit Grave Culture (late fourth to mid-third millenium BC)? In: V. Heyd, G. Kulcsár, V. Szeverényi (Eds), Transition to the Bronze Age. Interregional interaction and socio-cultural change in the third millenium BC. Carpathian Basin and neighbouring regions, 113-138. Budapest.

Rassamakin Y.Y., Evdokimov G.L.

2002 Novyi eneoliticheskiy mogilnik na r. Ingulets y problema vydelenyia "poststogovskikh" pogrebeniy. Arkheologicheskiy almanakh 10: 71-86.

Razumow S., Kośko A., Karnaukh E., Manigda O.

2013 Zvit pro robotu spilnoyi ukrainsko-polskoyi Yampilskoi arkheolohichnoyi ekspedytsii $v 2012$ rotsi (held in the archives of IA NANU). Kyiv.

Tkachuk T.M.

2001-2002 Konets etapa CI i nachalo CII tripolskoy kultury verkhnego Podnestrovia (na materialakh poselenia Bilshivtsi. Stratum plus 2: 196-217.

Yarovoy E.V.

1978 Otchet o polevykh issledovaniyakh eneoliticheskoy archeologicheskoy ekspeditsii v 1977 godu. Kishinev.

2001 Eneoliticheskie sviatilischa y antropomorfnye stely Dnestrovsko-Prutskogo mezhdurechia. In: Davnia istoriya Ukrayiny i sumizhnykh rehioniv. Carpatica 13. Yuvileynyi zbirnyk na chest 70-richchia vid dnia narodzhennia prof. E.A. Balaguri, 67-77. Uzhhorod.

Zhuravlov O.

2013 Vyznachennia osteolohichnykh materialiv z kurhany 1 bilia s. Klembivka (held in the archives of IA NANU). Kyiv. 